\title{
Interventions for treating oral leukoplakia (Review)
}

\author{
Lodi G, Sardella A, Bez C, Demarosi F, Carrassi A
}

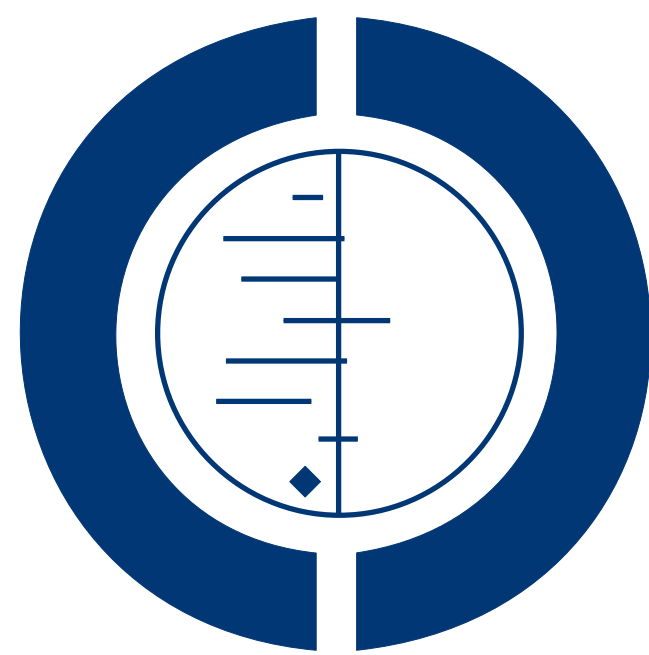

\section{THE COCHRANE COLLABORATION $^{\circledR}$}

This is a reprint of a Cochrane review, prepared and maintained by The Cochrane Collaboration and published in The Cochrane Library 2006, Issue 4

http://www.thecochranelibrary.com

\section{WILEY}


TABLE OF CONTENTS

HEADER . . . . . . . . . . . . . . . . . . . . . . . . . . . . . . . . . . . . . . . 1

ABSTRACT . . . . . . . . . . . . . . . . . . . . . . . . . . . . . . . . . . . . . . . . . . . .

PLAIN LANGUAGE SUMMARY . . . . . . . . . . . . . . . . . . . . . . . . . . . . . . . . . . . . . . . . .

BACKGROUND . . . . . . . . . . . . . . . . . . . . . . . . . . . . . . . . . . . . .

Figure 1. . . . . . . . . . . . . . . . . . . . . . . . . . . . . . . . . . . . . .

Figure 2. . . . . . . . . . . . . . . . . . . . . . . . . . . . . . . . . . . . . . . 44

OBJECTIVES . . . . . . . . . . . . . . . . . . . . . . . . . . . . . . . . . . . . . . 44

METHODS . . . . . . . . . . . . . . . . . . . . . . . . . . . . . . . . 5

RESULTS . . . . . . . . . . . . . . . . . . . . . . . . . . . . . . . . . . . . . . . 6

DISCUSSION . . . . . . . . . . . . . . . . . . . . . . . . . . . . . . . . . . . . . . . . . . . . . . .

AUTHORS' CONCLUSIONS . . . . . . . . . . . . . . . . . . . . . . . . . . . . . . . . . . . . . .

ACKNOWLEDGEMENTS . . . . . . . . . . . . . . . . . . . . . . . . . . . . . . . . . . . . . . . . . . .

REFERENCES . . . . . . . . . . . . . . . . . . . . . . . . . . . . . . . . . . . . . . 9

CHARACTERISTICS OF STUDIES . . . . . . . . . . . . . . . . . . . . . . . . . . . . . . 12

DATA AND ANALYSES . . . . . . . . . . . . . . . . . . . . . . . . . . . . . . . . . . . . . 23

Analysis 1.1. Comparison 1 Topical or systemic treatment versus placebo, Outcome 1 Malignant transformation. . . . 23

Analysis 1.2. Comparison 1 Topical or systemic treatment versus placebo, Outcome 2 Oral lesion not completely resolved. 24

Analysis 1.3. Comparison 1 Topical or systemic treatment versus placebo, Outcome 3 Histological features not improved. 25

ADDITIONAL TABLES . . . . . . . . . . . . . . . . . . . . . . . . . . . . . . . . . . . . . . . . 26

APPENDICES . . . . . . . . . . . . . . . . . . . . . . . . . . . . . . . . . . . . . . . . . . . . . .

WHAT'S NEW . . . . . . . . . . . . . . . . . . . . . . . . . . . . . . . . . . . . . .

HISTORY . . . . . . . . . . . . . . . . . . . . . . . . . . . . . . . . . . . . . . . 28

CONTRIBUTIONS OF AUTHORS . . . . . . . . . . . . . . . . . . . . . . . . . . . . . . . . . . . . 28

DECLARATIONS OF INTEREST . . . . . . . . . . . . . . . . . . . . . . . . . . . . . . . . 28

SOURCES OF SUPPORT . . . . . . . . . . . . . . . . . . . . . . . . . . . . . . . . . . . . . . . . . . . . . . . .

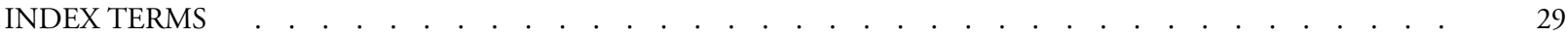

Interventions for treating oral leukoplakia (Review)

Copyright $\odot 2008$ The Cochrane Collaboration. Published by John Wiley \& Sons, Ltd. 


\title{
[Intervention Review]
}

\section{Interventions for treating oral leukoplakia}

\author{
Giovanni Lodi ${ }^{1}$, Andrea Sardella ${ }^{1}$, Cristina Bez ${ }^{1}$, Federica Demarosi $^{1}$, Antonio Carrassi ${ }^{1}$ \\ ${ }^{1}$ Oral Pathology and Oral Medicine, University of Milan, Milan, Italy \\ Contact address: Giovanni Lodi, Oral Pathology and Oral Medicine, University of Milan, Via Beldiletto 1/3, Milan, 20142, Italy. \\ giovanni.lodi@unimi.it.
}

Editorial group: Cochrane Oral Health Group.

Publication status and date: Edited (no change to conclusions), published in Issue 4, 2008.

Review content assessed as up-to-date: 3 July 2006.

Citation: Lodi G, Sardella A, Bez C, Demarosi F, Carrassi A. Interventions for treating oral leukoplakia. Cochrane Database of Systematic Reviews 2006, Issue 4. Art. No.: CD001829. DOI: 10.1002/14651858.CD001829.pub3.

Copyright (C) 2008 The Cochrane Collaboration. Published by John Wiley \& Sons, Ltd.

\begin{abstract}
A B S T R A C T
Background

Oral leukoplakia is a relatively common oral lesion that in a small but significant proportion of cases changes into cancer. Since most leukoplakias are asymptomatic, the primary objective of treatment should be to prevent such malignant transformation.
\end{abstract}

Objectives

To assess effectiveness, safety and acceptability of treatments for leukoplakia.

\section{Search methods}

The following databases were searched for relevant trials: Cochrane Oral Health Group's Trials Register (to April 2006), CENTRAL (The Cochrane Library 2006, Issue 1), MEDLINE (from 1966 to December 2005), and EMBASE (from 1980 to December 2005). Handsearching was performed for the main oral medicine journals. References of included studies and reviews were checked. Oral medicine experts were contacted through an European mailing list (EURORALMED).

\section{Selection criteria}

Randomised controlled trials (RCTs), enrolling patients with a diagnosis of oral leukoplakia, were included. Any surgical or medical (topical and systemic) treatment was included. The primary outcome considered was malignant transformation of leukoplakia. Other outcomes considered were clinical resolution, histological modification and frequency of adverse effects.

\section{Data collection and analysis}

Data were collected using a specific extraction form. Malignant transformation of leukoplakia, demonstrated by histopathological examination, was the main outcome considered. Secondary outcomes included clinical resolution of the lesion and variation in dysplasia severity. The validity of included studies was assessed by two review authors, on the basis of the method of allocation concealment, blindness of the study and loss of participants. Data were analysed by calculating risk ratio. When valid and relevant data were collected, a meta-analysis of the data was undertaken.

\section{Main results}

The possible effectiveness of surgical interventions, including laser therapy and cryotherapy, has never been studied by means of a RCT with a no treatment/placebo arm. Twenty-five eligible RCTs of non-surgical interventions were identified: 11 were excluded for different reasons, five were ongoing studies, leaving nine studies to be included in the review (501 patients). Two studies resulted at low risk of bias, six at moderate risk of bias and one at high risk of bias. Vitamin A and retinoids were tested by five RCTs, two studies 
investigated beta carotene or carotenoids, the other drugs tested were bleomycin (one study), mixed tea (one study) and ketorolac (one study). One study tested two treatments. Malignant transformation was recorded in just two studies: none of the treatments tested showed a benefit when compared with the placebo. Treatment with beta carotene, lycopene and vitamin A or retinoids, was associated with significant rates of clinical resolution, compared with placebo or absence of treatment. Whenever reported, a high rate of relapse was a common finding. Side effects of variable severity were often described; however, interventions were well accepted by patients, since drop-out rates were similar between treatment and control groups.

\section{Authors' conclusions}

To date there is no evidence of effective treatment in preventing malignant transformation of leukoplakia. Treatments may be effective in the resolution of lesion, however relapses and adverse effects are common.

\section{PLAIN LANGUAGE SUMMARY}

\section{Interventions for treating oral leukoplakia}

No evidence from trials to show how to prevent leukoplakia in the mouth becoming malignant.

Oral leukoplakia is a thickened white patch formed in the mouth lining that cannot be rubbed off. Leukoplakia is a lesion that sometimes becomes cancerous (a tumour that invades and destroys tissue, then spreads to other areas). Preventing this change is critical as survival rates of more than 5 years after diagnosis with oral cancer is low. Drugs, surgery and other therapies have been tried. The review of trials compared several drugs such as bleomycin, vitamin A and beta carotene supplements and mixed tea. There was no evidence found to show the effects of these treatments. More research is needed.

\section{B A C K G ROU N D}

"Oral leukoplakia is a predominantly white lesion of the oral mucosa that cannot be characterised as any other definable lesion" (Axell 1996). Such a definition, also adopted by the World Health Organization (WHO), is the result of the effort of an international group of experts, who met in Uppsala in 1994 in order to review leukoplakia definitions and classifications on the basis of previously published work (Axell 1984; Kramer 1978) and new scientific acquisitions. Thus, leukoplakia is a clinical term used when any other white oral lesion has been excluded. Leukoplakia is often associated with tobacco smoking, although idiopathic forms are not rare (Axell 1987). The role of alcohol, viruses and systemic conditions need further investigations (Campisi 2004; Dietrich 2004).

Clinical variants of leukoplakia are classified into two groups: (1) homogeneous leukoplakia, a lesion of uniform flat appearance that may exhibit superficial irregularities, but with consistent texture throughout (Figure 1); (2) non-homogeneous leukoplakia, a predominantly white or white and red lesion (erythroleukoplakia) with an irregular texture that may be characterised by a flat, nodular or exophytic aspect (Figure 2). Histological features of both forms of leukoplakia are quite variable and may include ortho- or para-keratosis of various degrees, mild inflammation and dysplastic changes of various degrees. 
Figure I. Homogeneous leukoplakia of the lateral border of the tongue

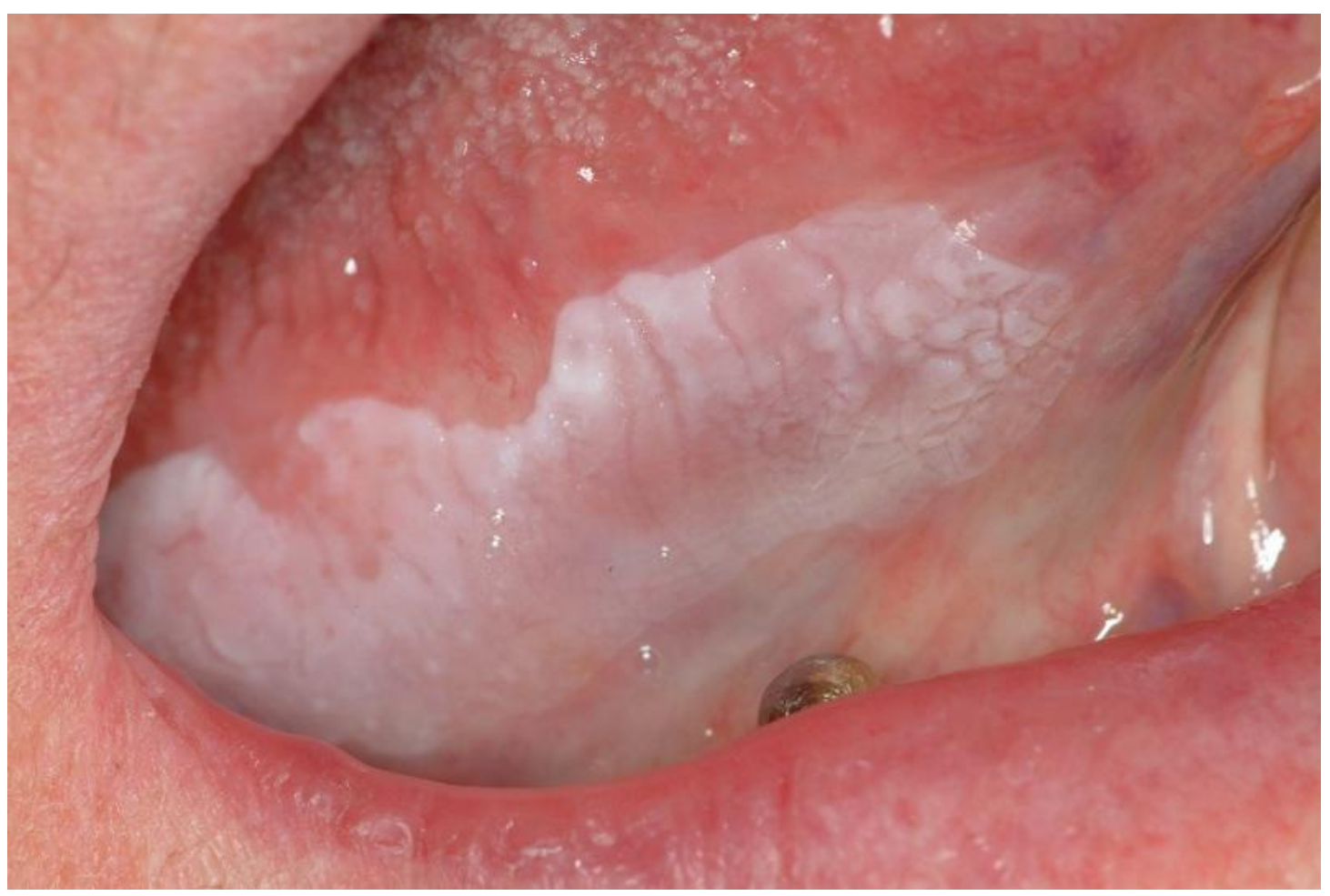


Figure 2. Non-homogeneous leukoplakia of the lateral border of the tongue

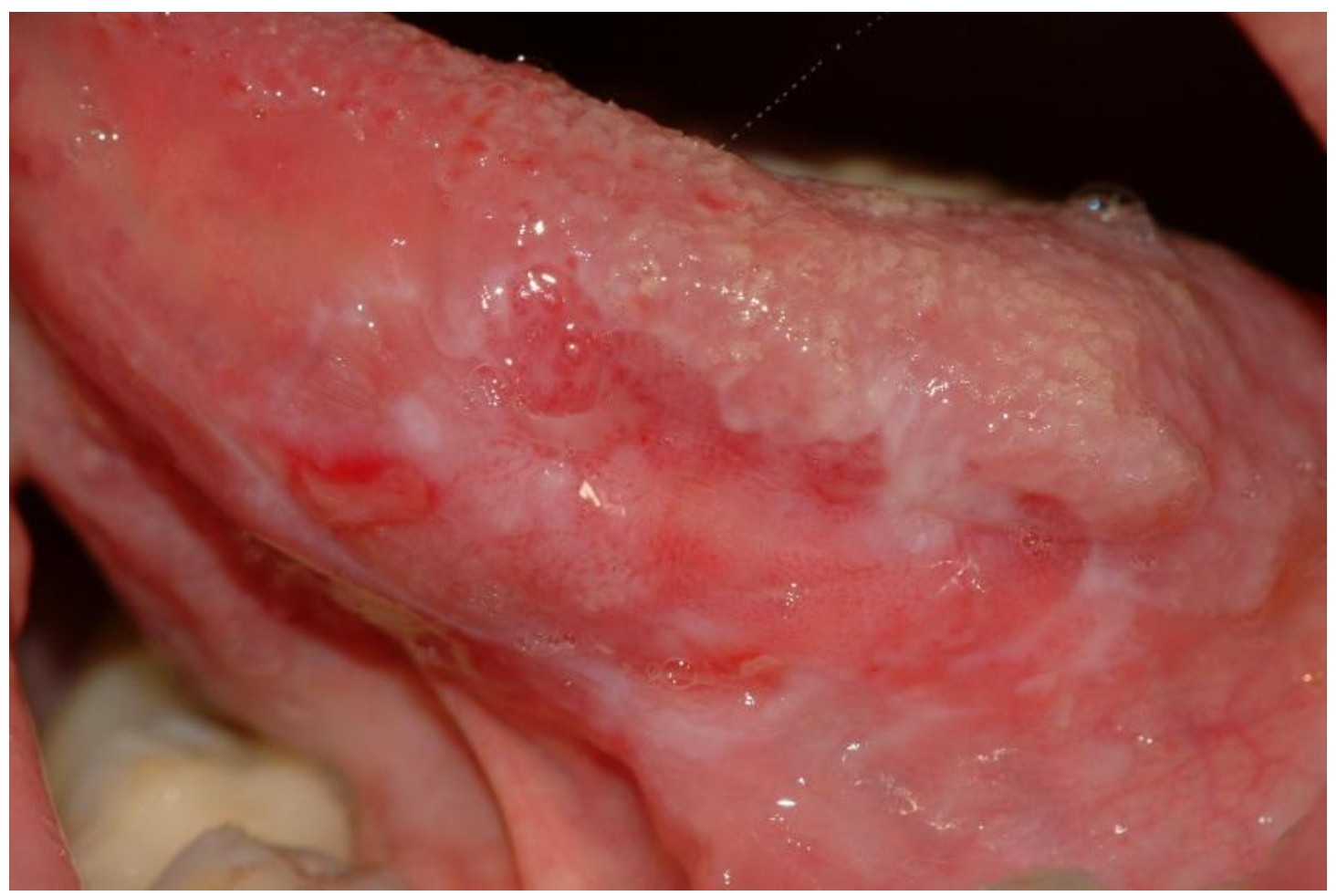

Leukoplakia is not uncommon. Although highly variable among geographical areas and demographical groups, the prevalence of leukoplakia in the general population varies from less than $1 \%$ to more than 5\% (Axell 1984; Axell 1987; Bouquot 1986; Ikeda 1991; Reichart 2000). In a recent systematic review, when studies with more than 1000 individuals were included, prevalence varied between $0.50 \%$ and $3.46 \%$, and the pooled prevalence estimated was between $1.49 \%$ and $4.27 \%$ (Petti 2003). Incidence data are very scarce, a recent study from Japan reported an age-adjusted incidence rate per 100,000 persons-years of 409.2 among males and 70 among females (Nagao 2005), while an Indian study, conducted in a population with distinctive risk factors for oral cancer, reported lower figures: 240 among males and 3 among females (Gupta 1980).

Leukoplakia is a precancerous lesion, i.e. "a morphologically altered tissue in which cancer is more likely to occur than in its apparently normal counterpart" (Axell 1996). The rate of malignant transformation into squamous cell carcinoma varies from almost $0 \%$ to about $20 \%$ in 1 to 30 years (Lind 1987; Schepman 1998; Silverman 1984). Recently, a study investigating the natural limit of leukoplakia malignant transformation on the basis of European epidemiological data, concluded that the upper limit of the annual transformation rate of oral leukoplakia is unlikely to exceed $1 \%$ (Scheifele 2003).
Non-homogeneous leukoplakias carry a higher degree of risk of transformation when compared with the homogeneous variants. Patients with signs of dysplasia, about $1 / 10$ of the total, may be at a higher risk. However, studies investigating biomarkers and histological features have found no reliable method to identify which lesion will undergo malignant transformation and which will not (Warnakulasuriya 2000). Clinical (Zhang 2005), histological (Lee 2000) and molecular markers (Zhang 2001) may contribute in assessing the risk of a single patient to develop cancer, however a single, evidence-based and clinically useful predictor of malignant transformation for dysplastic and non-dysplastic leukoplakias, is not available at the moment.

Since most leukoplakias are asymptomatic, the need for treatment is primarily based on the precancerous nature of the lesion. Prevention of malignant transformation is particularly important in view of the poor prognosis associated with oral squamous cell carcinoma, with only $30 \%$ to $40 \%$ of patients still alive 5 years after the diagnosis (Scully 2000). Many treatments have been proposed for oral leukoplakias (including medical and surgical therapies).

\section{O B J E C T I V E S}

Interventions for treating oral leukoplakia (Review)

Copyright @ 2008 The Cochrane Collaboration. Published by John Wiley \& Sons, Ltd. 
To compare the outcomes for patients affected by oral leukoplakia, undergoing medical or surgical treatments or both compared with placebo or no treatment.

\section{METHODS}

\section{Criteria for considering studies for this review}

\section{Types of studies}

Randomised controlled trials (RCTs) and quasi-randomised controlled trials were included.

\section{Types of participants}

Anyone with a diagnosis of oral leukoplakia as defined, at the time of the studies, by the consensus conferences held in 1978, 1983, 1994 (Axell 1984; Axell 1996; Kramer 1978).

\section{Types of interventions}

\section{Active}

- Surgical removal of the lesion, including surgical excision, laser surgery, cryotherapy.

- Topical medical treatment, including anti-inflammatory agents, antimycotic agents, carotenoids and retinoids, cytotoxic agents, etc.

- Systemic medical treatment.

- Removal of predisposing habits (e.g. tobacco, alcohol, etc.).

- Other treatment (e.g. photodynamic therapy).

- Combined treatment.

\section{Control}

- Placebo.

- No treatment.

\section{Types of outcome measures}

\section{Primary outcomes}

Because of the precancerous nature of leukoplakia, the primary objective of treatment is to prevent malignant transformation. Thus leukoplakia morbidity, in terms of frequency of malignant transformation, demonstrated by histopathological examination, was the main outcome considered.

\section{Secondary outcomes}

As epithelial dysplasia may already be present at the time of diagnosis, variation in histological features was also included in the outcome measures.

For interventions directed toward elimination of the lesion, especially by surgical methods, long term resolution and proportion of relapsing lesions were considered.

Outcome measures included safety and acceptability of the intervention, as measured by the incidence of adverse effects and proportion of patients dropping out respectively.

\section{Search methods for identification of studies}

The databases searched were:

The Cochrane Oral Health Group's Trials Register (April 2006)

The Cochrane Central Register of Controlled Trials (CENTRAL)

(The Cochrane Library 2006, Issue 1)

MEDLINE (from 1966 to December 2005)

EMBASE (from 1980 to December 2005)

The database of the National Cancer Institute (www.cancer.gov), previously hosting CancerLit.

Sensitive search strategies were developed for each database (available from the review authors on request) using a combination of free text and $\mathrm{MeSH}$ terms such as leukoplakia, oral precancer, oral preneoplastic lesion. The search strategy for CENTRAL is given as an example in Appendix 1.

The $m e t a$ Register of Controlled Trials was searched for relevant trials (www.controlled-trials.com).

Language: studies in all languages were considered for translation. Reference lists of included studies and existing reviews were checked.

In order to detect unpublished and ongoing trials, a formal letter requesting information was sent to Oral Medicine experts by EURORALMED, an electronic mailing list reaching a vast number of colleagues, mainly from European countries. Pharmaceutical companies were also contacted.

The following journals were identified as being important to be handsearched for the review:

- Cancer

- Community Dentistry and Oral Epidemiology

- European Journal of Oral Sciences

- Journal of Dental Research

- Oral Oncology

- Oral Surgery, Oral Medicine, Oral Pathology, Oral Radiology and Endodontics.

The journal issues not already covered by the Cochrane worldwide handsearching programme (www.cochrane.org) were handsearched (January 1999 onwards). 


\section{Data collection and analysis}

The title and abstract of each article resulting from the different search strategies were examined separately by two review authors. When at least one review author considered the article relevant, it progressed in the review process and was included in a digital archive prepared using a dedicated software. Full reports were obtained for all relevant studies.

\section{Critical appraisal of studies}

Every study reporting a randomised or quasi-randomised clinical trial was assessed by two review authors according to the criteria for randomised trial data suggested by Cochrane Handbook for Systematic Reviews of Interventions 4.2.5 (Higgins 2005) and EvidenceBased Medicine. How to practice and teach EBM (Sackett 1997). In particular the study's validity was judged on the basis of.

- Method of allocation concealment. It was considered 'adequate' when the assignment of patients to treatments was randomised and the randomisation schedule was kept concealed to the researcher recruiting participants. When papers did not report such information, the criterion was considered 'unclear'.

- Protection against performance bias (blindness of the study). The criterion was considered 'met' when patients and researchers assessing outcome measures were kept 'blind', and 'partially met' when only one group (patients or researchers) was kept 'blind'. When blinding was not possible (as in surgical treatment) this criterion was not considered in the validity rating of the study.

- Losses of participants. At least $80 \%$ of patients who entered the trial should be included in the final analysis.

Each of these criteria was rated as 'met', 'partially met', 'unmet', or 'unclear'. The global validity of the study was assessed using three categories.

(1) Low risk of bias: all of the criteria met.

(2) Moderate risk of bias: one or more criteria partially met.

(3) High risk of bias: one or more criteria unmet or unclear.

The critical appraisal of the studies was carried out without blinding the name of authors, institutions and journal. Data about the study, its eligibility, validity, design and outcome information, were recorded by each reviewer on an extraction form. In case of disagreement, consensus was achieved by discussion and a new form was completed.

\section{Statistical analyses}

When valid and relevant data were collected, a meta-analysis of the data was undertaken. For each intervention, statistical analyses evaluated the available data on differences among effects in terms of morbidity (i.e. malignant changes), relapse (for interventions directed toward elimination of the lesion), adverse effects and patients dropping out.
The primary measure of intervention effect was reduction of morbidity, as indicated by the difference in incidence of malignant changes, between the control and intervention groups.

Dichotomous data were expected for the main outcome measure (cancerization versus absence of cancerization). In case of variations in histological features, the data were dichotomised in decreased severity or no change in histological features versus getting worse. Other dichotomous data included, incidence of adverse effects and frequency of drop-out patients.

For each intervention, data on the number of patients of intervention and control groups who experienced the event (outcome) and the total number of patients, were sought and summarised. Dichotomous data were analysed by calculating risk ratios. As we pooled together data from studies in which true treatment effects are likely to differ, a random-effects model has been used in the statistical analyses.

Missing data were obtained from tables and graphs or by contacting the authors.

Subgroup analysis was undertaken for class of drug (vitamin A and retinoids). Subgroup analyses for smoking and non-smoking patients, and for lesions with or without dysplasia, were not possible because such data were not available.

A sensitivity analysis was undertaken, excluding studies of lower methodological quality (i.e. studies at high risk of bias).

\section{RES U L T S}

\section{Description of studies}

See: Characteristics of included studies; Characteristics of excluded studies; Characteristics of ongoing studies.

We found only one randomised controlled trial (RCT) evaluating surgical interventions (Schwarz 2005), unfortunately it did not include a no treatment/placebo group, and for this reason it was excluded from the review (see Criteria for considering studies for this review). Twenty-five potentially eligible RCTs were identified: 11 were excluded (see Characteristics of excluded studies table) and five were ongoing studies (Beenken 2000; Boyle 2000; Chiang 2005; Goodin 2005; Lippman 2004), leaving nine studies to be included in the review. Three of the included studies were a threearm trial (Gaeta 2000; Sankaranarayan 1997; Singh 2004), but in two of them we pooled together the data of the active arms: in one case the two interventions differ only in lactose content (a putative non-active component) (Gaeta 2000), in the other the interventions differ in dosage (Singh 2004).

Four RCTs compared topical treatment versus placebo (totaling 100 patients) (Epstein 1994; Gaeta 2000; Mulshine 2004; Piattelli 1999), four RCTs compared systemic treatment versus placebo (totaling 327 patients) (Hong 1986; Sankaranarayan 
1997; Singh 2004; Stich 1988). One RCT compared an association of topical and systemic treatments with placebo (64 patients) (Li 1999). Vitamin A and retinoids were tested by five RCTs (245 patients) (Gaeta 2000; Hong 1986; Piattelli 1999; Sankaranarayan 1997; Stich 1988), two studies investigated beta carotene (Sankaranarayan 1997) and a carotenoid (lycopene) (Singh 2004). The other drugs tested were bleomycin (Epstein 1994), mixed tea (a mixture of whole water extract of green tea, green tea polyphenols, and tea pigments in the ratio of $4: 1: 1)$ ( $\mathrm{Li}$ 1999), and ketorolac (Mulshine 2004). The total number of patients of the included studies was 501 .

In all patients enrolled in the studies a biopsy had been taken to confirm the diagnosis of leukoplakia, however only two studies reported the histologic criteria used (Epstein 1994; Stich 1988). Five studies reported the percentage of dysplastic lesions that varied from $20 \%$ to $59 \%$. In one study dysplastic lesions were in the treatment arms but not in the control group (Gaeta 2000).

The reported proportion of smoking and drinking patients (the two main risk factors for oral cancer) varied from $30 \%$ to $86 \%$ and from $18 \%$ to $86 \%$, respectively. None of the authors reported significant changes in these habits during the course of the trial. In two studies (Sankaranarayan 1997; Stich 1988) the totality of subjects recruited were chewers of tobacco-containing betel quid (another well known risk factor for oral cancer) from the same Indian village (Trivandrum, Kerala).

The follow-up period since the end of treatment was reported in five RCTs (Epstein 1994; Hong 1986; Mulshine 2004; Sankaranarayan 1997; Singh 2004), varying from 1 to 15 months. Only two studies reported useful data on cancer development ( Epstein 1994; Sankaranarayan 1997); in Epstein's trial only part of the placebo group was taken into account, as 7 out of 12 patients of this group received the active treatment at the end of the study period, and thus were excluded from the placebo group for this outcome.

All the included studies reported clinical changes of leukoplakias. A complete response was defined as the complete disappearance of the lesion in seven RCTs; six of them had also the same definition for partial response (greater than $50 \%$ reduction), while one had slightly different criteria (greater than $30 \%$ reduction) (Li 1999). One RCT categorised the response of leukoplakias into three groups (remission, no change, new leukoplakia) and another used a three value descriptive clinical scale, in both cases the criteria were not specified. Assessment of the histological modifications following the treatment was reported by four RCTs (Epstein 1994; Gaeta 2000; Hong 1986; Singh 2004); one RCT investigated some biomarkers of DNA damage and cell proliferation ( $\mathrm{Li}$ 1999), but the results of this study were not included as not comparable with the previous two. A further study reported histological changes in the treatment group only (Stich 1988).

\section{Risk of bias in included studies}

On the basis of the criteria used in the critical appraisal of the studies, two studies resulted in a low risk of bias (Epstein 1994; Hong 1986). In both studies the methods of allocation concealment were adequate and reported in detail, and more than $80 \%$ of the patients who entered the study were included in the final analysis. Six randomised controlled trials (RCTs) were judged at moderate risk of bias (Gaeta 2000; Li 1999; Mulshine 2004; Piattelli 1999; Sankaranarayan 1997; Singh 2004), one of them was a quasi-randomised trial, while in the other the methods of allocation concealment were not described. The remaining study (Stich 1988) was considered at high risk of bias because of the unclear method of allocation concealment and the absence of protection against performance bias (blindness of the study).

\section{Effects of interventions}

\section{Malignant transformation (Comparison I, Outcome I.I)}

Results from two studies, including 172 patients, were available for the analyses (as one of the studies has a three-arm design, the control group is indicated twice in the plot). Three drugs were evaluated in these studies: topical bleomycin (Epstein 1994), systemic vitamin A (Sankaranarayan 1997) and systemic beta carotene (Sankaranarayan 1997). None of the treatments in these studies showed a benefit when compared with the placebo.

\section{Clinical resolution (Comparison I, Outcome I.2)}

Data on complete resolution of the oral lesions were available from all the nine studies included in the review (501 patients). Three treatments (bleomycin, ketorolac and tea) were only assessed in single studies and these treatments showed no benefit when compared to the placebo/control group. Two studies (Sankaranarayan 1997; Singh 2004) showed a significant benefit for the systemic treatment with beta carotene or lycopene (a carotenoid) when compared to the control (risk ratio (RR) Random $=0.69$; $95 \%$ confidence interval (CI) 0.54 to 0.88 ). Five studies investigated the effectiveness of vitamin A or retinoids (Gaeta 2000; Hong 1986; Piattelli 1999; Sankaranarayan 1997; Stich 1988) and found a small but significant benefit $\left(\mathrm{RR}_{\text {Random }}=0.69 ; 95 \%\right.$ CI 0.50 to 0.96 ). Two of these studies employed topical retinoids (Gaeta 2000; Piattelli 1999).

Among patients treated with topical bleomycin (Epstein 1994), two out of four patients with a complete response, for whom follow-up information was available, relapsed; the same happened for one out of two patients with a partial response and follow-up data. Sankaranarayanan's study reported that 14 out of $22(64 \%)$ complete responders of the first arm and 8 out of 15 (54\%) complete responders of the second arm developed recurrent lesions (no information was available regarding the three complete responders 
of the placebo group) (Sankaranarayan 1997). Relapses were also reported by Hong and colleagues: 9 out of 16 (56\%) patients responding to treatment (partially or completely) relapsed (no information was available regarding the two partial responders of the placebo group) (Hong 1986). In Piattelli's study one out of five $(20 \%)$ patients responding to the experimental treatment and one out of four $(25 \%)$ patients responding to placebo relapsed (Piattelli 1999). No data on relapses were available for the other studies.

\section{Histological changes}

Histological changes were available from four studies (Epstein 1994; Gaeta 2000; Hong 1986; Singh 2004), but comparison was possible only for three of them, in fact in Gaeta's study, the absence of dysplastic lesions in the control group made impossible a comparison. In the other three studies the histological aspect of oral lesions did not improve (i.e. was stable or got worse) more frequently with placebo than with active treatment, and the difference was significant when retinoic acid $\left(\mathrm{RR}_{\text {Random }}=0.51 ; 95 \%\right.$ CI 0.32 to 0.81 ) (Hong 1986) or lycopene ( $\mathrm{RR}_{\text {Random }}=0.24$; 95\% CI 0.12 to 0.46 ) (Singh 2004) were employed.

\section{Safety and acceptability}

Frequency of adverse effects varied largely among studies. Topical 13-cis-retinoic acid, 200,000 IU per week of vitamin A, topical acitretin (10 mg twice per day), mixed tea and lycopene did not cause any adverse effects. Topical bleomycin, systemic 13-cisretinoic acid ( 1 to $2 \mathrm{mg} / \mathrm{kg} /$ day), ketorolac oral rinse, vitamin A (300,000 IU per week) and beta carotene $(360 \mathrm{mg} / \mathrm{week})$, caused adverse effects of various severity in 100\%, 79\%, 29\%, 26\% and $9 \%$ of patients, respectively (Table 1 ). Whenever present, adverse effects were always more common in the study group than in the control group. Adverse effects caused patients to withdraw in two studies only: when systemic 13-cis-retinoic acid induced severe conjunctivitis and hypertrigliceridemia and following an intolerable mouth pain following first ketorolac mouthrinse. Information on the reasons for patient withdrawal were missing in five out of six studies that reported at least one missing patient.

In spite of adverse effects, treatment acceptability was good, as drop-out rates between treatments and placebo were similar in all but one study (Table 2).

\section{ISCUSSIO N}

Leukoplakia is the most common precancerous oral lesion. Although rates of malignant transformation may vary among studies, probably due to differences in diagnostic criteria and followup intervals, the morbidity and mortality associated with oral cancer make leukoplakia a serious health problem. Nevertheless, we found only nine studies to include in the present review, none of these evaluated a surgical intervention. They showed little evidence for an effective treatment in the prevention of malignant transformation. There was some evidence that vitamin A, retinoids, beta carotene and lycopene may completely resolve the oral lesions, and that retinoic acid and lycopene may promote histological improvement, although this last result is only based on a small number of patients.

Less than half (33\% to $42 \%$ ) of leukoplakias which undergo malignant change, does so within 2 years of diagnosis (Lind 1987; Silverman 1984) and the incidence of malignant transformation increases with the duration of follow up (Shiu 2000). Therefore, in order to properly assess modifications in the rates of leukoplakia malignant transformation, it would be necessary to plan studies with large groups of patients and a long follow up: that means multicentre randomised controlled trials (RCTs). However, the mean follow up of the studies included in the review was no longer than 15 months, thus the transformation rates could be underestimated. Besides, some researchers used outcomes different from cancer development, in particular various cytological or histological markers or both. Although easier to perform, studies using such outcomes pose a double problem: first there is little evidence of the predictive value of many of those outcomes; second, they are hardly comparable. In addition, widespread outcomes such as dysplasia grade, may be affected by high observer variation (Abbey 1995; Karabulut 1995). The applicability of the results of two of the studies included (Sankaranarayan 1997; Stich 1988) should be considered very carefully; in fact the patients included in those studies were all betel chewers, a risk factor not common in individuals from geographical areas outside the Indian subcontinent.

Leukoplakias with different histological or molecular characteristics may have different risks of turning into a cancer. However the value of the prognostic factors proposed so far in the literature still need sound confirmatory data. The presence of epithelial dysplasia may be predictive of a transformation to oral cancer and the risk of cancer incidence may increase with the severity of dysplastic changes (Lumerman 1995; Schepman 1998), although this hypothesis has been recently challenged (Holmstrup 2006). Unfortunately the data available did not allow us to perform a subgroup analysis of lesions with and without dysplasia, thus it is not possible to establish if any particular treatment may be more indicated in the presence of dysplasia of different severity. Many different molecular biomarkers have been proposed, still no one seems convincing enough to be applied to clinical routine. Recently, studies on a very promising prognostic marker, cited in the previous version of this review, are being investigated for accuracy (Curfman 2006), following a case of scientific fraud (Horton 2006).

Leukoplakias are not morbid or lethal by themselves and have a relatively low risk of transformation. As a consequence many subjects receiving treatments have lesions that will never progress to 
cancer. For this reason proposed treatments should have minimal adverse effects in terms of incidence and severity. This is not the case for some of the interventions evaluated. In particular, high doses of retinoids may cause toxic effects severe enough to cause patients to stop treatment. However, in all but one trial the number of patients leaving the study group was not much bigger than the number of those leaving the placebo group (and in one study it was bigger in patients taking the placebo arm than in the two treatment arms).

It is noteworthy the absence of RCTs comparing the effects of surgical excision versus no treatment or placebo, surgery being the first choice in leukoplakia management for many clinicians (Marley 1998). The only data available are from follow-up studies comparing rates of malignant transformation in patients who did and did not undergo surgical treatment of oral leukoplakias. Although results from such studies are hardly comparable because of differences in diagnostic and inclusion criteria, follow-up interval, patient characteristics and surgical techniques employed (scalpel, laser, cryotherapy), they show highly variable results and sometimes are conflicting in the conclusions (Saito 2001; Schepman 1998).

Trials evaluating interventions directed against risk factors (i.e. smoking) are also missing.

\section{AUTHORS' CONCLUSIONS}

\section{Implications for practice}

None of the treatments studied was shown to be effective in preventing malignant transformation of leukoplakias.
Some treatments were effective in healing oral leukoplakia, however they did not seem able to prevent relapses and malignant change. For this reason the clinical healing of leukoplakia following one of these treatments, does not release the clinician from the duty of regular follow up.

\section{Implications for research}

Although surgery remains the first option for most clinicians, the real effectiveness of such treatment cannot be assessed, as it was not possible to find any randomised controlled trials of surgery versus no treatment (wait and see) in the prevention of malignant transformation of leukoplakia, the only randomised controlled trial comparing two laser techniques. Research is needed to assess surgery in the treatment of leukoplakia.

Until definitive evidence on the predictive value of specific biomarkers becomes available, malignant transformation should be considered the best outcome to take into account in testing the effectiveness of treatments for leukoplakia.

More research is needed to evaluate the effects of risk factor cessation on the malignant transformation of leukoplakia.

\section{ACKNOWLEDGEMENTS}

The review authors wish to thank Chiara Procchio for help during most of the work. Elena Telaro, Emma Tavender, Helen Worthington and Marco Esposito for their continuous support. All the researchers of the cited studies who have provided some of the data used in the review and the referees for their precious suggestions.

\section{R E F E R E N C E S}

\section{References to studies included in this review}

Epstein 1994 \{published and unpublished data\}

Epstein JB, Wong FL, Millner A, Le ND. Topical bleomycin treatment of oral leukoplakia: a randomized double-blind clinical trial. Head \& Neck 1994;16(6):539-44.

Gaeta 2000 \{published and unpublished data\} Gaeta GM, Gombos F, Femiano F, Battista C, Minghetti P, Montanari L, et al.Acitretin and treatment of the oral leucoplakias. A model to have an active molecules release. Journal of the European Academy of Dermatology and Venereology 2000;14(6):473-8.

Hong 1986 \{published data only\}

Hong WK, Endicott J, Itri LM, Doos W, Batsakis JG, Bell R, et al.13-cis-retinoic acid in the treatment of oral leukoplakia. New England Journal of Medicine 1986;315 (24):1501-5.
Li 1999 \{published and unpublished data\}

Li N, Sun Z, Han C, Chen J. The chemopreventive effects of tea on human oral precancerous mucosa lesions. Proceedings of the Society for Experimental Biology and Medicine 1999;220(4):218-24.

Mulshine 2004 \{published data only\} Mulshine JL, Atkinson JC, Greer RO, Papadimitrakopoulou VA, Van Waes C, Rudy S, et al.Randomized, double-blind, placebo-controlled phase IIb trial of the cyclooxygenase inhibitor ketorolac as an oral rinse in oropharyngeal leukoplakia. Clinical Cancer Research 2004;10(5):1565-73.

Piattelli 1999 \{published and unpublished data\}

Piattelli A, Fioroni M, Santinelli A, Rubini C. bcl-2 expression and apoptotic bodies in 13-cis-retinoic acid (isotretinoin)-topically treated oral leukoplakia: a pilot study. Oral Oncology 1999;35(3):314-20. 
Sankaranarayan 1997 \{published data only\}

Sankaranarayanan R, Mathew B, Varghese C, Sudhakaran

PR, Menon V, Jayadeep A, et al.Chemoprevention of oral leukoplakia with vitamin A and beta carotene: an assessment. Oral Oncology 1997;33(4):231-6.

Singh 2004 \{published data only\}

Singh M, Krishanappa R, Bagewadi A, Keluskar V. Efficacy of oral lycopene in the treatment of oral leukoplakia. Oral Oncology 2004;40(6):591-6.

Stich 1988 \{published data only\}

Stich HF, Hornby AP, Mathew B, Sankaranarayanan R, Nair MK. Response of oral leukoplakias to the administration of vitamin A. Cancer Letters 1988;40(1):93-101.

\section{References to studies excluded from this review}

Bocharova 2004 \{published data only\}

Bocharova OA, Pozharitskaya MM, Chekalina TL, Lyzhenkova MA, Karpova RV, Mezentseva MV, et al.Leukoplakia of oral mucosa: pathogenesis and possible correction with phytoadaptogen. Bulletin of Experimental Biology and Medicine 2004;138(6):578-83.

Boisnic 1994 \{published data only\}

Boisnic S, Branchet MC, Pascal F, Ben Slama L, Rostin M, Szpirglas H. Topical tretinoin in the treatment of lichen planus and leukoplakia of the mouth mucosa. A clinical evaluation [Trétinoine topique dans le traitement des lichens plans et des leucoplasies de la muqueuse buccale. Evaluation clinique]. [French]. Annals of Dermatology and Venereology 1994;121(6-7):459-63.

Chiesa 2005 \{published data only\}

* Chiesa F, Tradati N, Grigolato R, Boracchi P, Biganzoli $\mathrm{E}$, Crose N, et al.Randomized trial of fenretinide (4-HPR) to prevent recurrences, new localizations and carcinomas in patients operated on for oral leukoplakia: long-term results. International Journal of Cancer 2005;115(4):625-9.

Chiesa F, Tradati N, Marazza M, Rossi N, Boracchi P, Mariani L, et al.Fenretinide (4-HPR) in chemoprevention of oral leukoplakia. Journal of Cellular Biochemistry Supplement 1993;17F:255-61.

Chiesa F, Tradati N, Marazza M, Rossi N, Boracchi P, Mariani L, et al.Prevention of local relapses and new localisations of oral leukoplakias with the synthetic retinoid fenretinide (4-HPR). Preliminary results. European Journal of Cancer. Part B, Oral Oncology 1992;28B(2):97-102. Costa A, Formelli F, Chiesa F, Decensi A, De Palo G, Veronesi U. Prospects of chemoprevention of human cancers with the synthetic retinoid fenretinide. Cancer Research 1994;54(7 Suppl):2032s-7s.

De Palo G, Veronesi U, Marubini E, Camerini T, Chiesa F, Nava M, et al.Controlled clinical trials with fenretinide in breast cancer, basal cell carcinoma and oral leukoplakia. Journal of Cellular Biochemistry Supplement 1995;22:11-7.

Femiano 2001 \{published data only\}

Femiano F, Gombos F, Scully C, Battista C, Belnome G, Esposito V. Oral leukoplakia: open trial of topical therapy with calcipotriol compared with tretinoin. International Journal of Oral and Maxillofacial Surgery 2001;30(5):402-6.

Garewal 1999 \{published data only\}

Garewal H, Pitcock J, Friedman S, Alberts D, Meyskens F, Ramsey L, et al.Beta-carotene in oral leukoplakia. Proceedings, Annual Meeting of the American Society of Clinical Oncology 1992;11:141.

* Garewal HS, Katz RV, Meyskens F, Pitcock J, Morse D, Friedman S, et al.Beta-carotene produces sustained remissions in patients with oral leukoplakia: results of a multicenter prospective trial. Archives of Otolaryngology Head and Neck Surgery 1999;125(12):1305-10.

Krishnaswamy 1995 \{published data only\}

Krishnaswamy K, Prasad MP, Krishna TP, Annapurna VV, Reddy GA. A case study of nutrient intervention of oral precancerous lesions in India. European Journal of Cancer. Part B: Oral Oncology 1995;31B(1):41-8.

Lippman 1993 \{published data only\} * Lippman SM, Batsakis JG, Toth BB, Weber RS, Lee JJ, Martin JW, et al.Comparison of low-dose isotretinoin with beta carotene to prevent oral carcinogenesis. New England Journal of Medicine 1993;328(1):15-20.

Papadimitrakopoulou VA, Lippman SM, Lee JS, Toth BB, Martin JW, Lee JJ, et al.Long term follow-up of low-dose isotretinoin (13-cRA) versus beta carotene to prevent oral carcinogenesis. Proceedings, Annual Meeting of the American Society of Clinical Oncology 1996;15:A340.

Mathew 1995 \{published data only\}

Mathew B, Sankaranarayanan R, Nair PP, Varghese C, Somanathan T, Amma BP, et al.Evaluation of chemoprevention of oral cancer with Spirulina fusiformis. Nutrition and Cancer 1995;24(2):197-202.

Schwarz 2005 \{published data only\}

Schwarz F, Maraki D, Yalcinkaya S, Bieling K, Bocking A, Becker J. Cytologic and DNA-cytometric follow-up of oral leukoplakia after CO2- and Er:YAG-laser assisted ablation: a pilot study. Lasers in Surgery and Medicine 2005;37(1): 29-36.

Sun 1996 \{published data only\}

Sun Z, Shen S, Liu-X. [Treatment of oral leukoplakia with retinamide]. [Chinese]. Chung-Hua-Kou-Chiang-HsuehTsa-Chib 1996;31(3):185-7.

Zaridze 1993 \{published data only\} Zaridze D, Evstifeeva T, Boyle P. Chemoprevention of oral leukoplakia and chronic esophagitis in an area of high incidence of oral and esophageal cancer. Annals of Epidemiology 1993;3(3):225-34.

\section{References to ongoing studies}

\section{Beenken 2000 \{published data only\}}

Beenken SW. Fenretinide in treating patients with leukoplakia of the mouth. www.controlled-trials.com/mrct/ trial/NCT00004161/1059/60505.html (2000). [: NLM identifier NCT00004161] 
Boyle 2000 \{unpublished data only\}

Boyle J. Celecoxib in treating patients with precancerous lesions of the mouth. www.controlled-trials.com/mrct/ trial/NCT00014404/1059/60207.html (2000). [: NLM Identifier NCT00014404]

Chiang 2005 \{published data only\}

Chiang C-P. Photodynamic therapy for oral leukoplakia and erythroleukoplakia. www.controlled-trials.com/ $\mathrm{mrct} / \mathrm{trial} / \mathrm{NCT} 00155337 / 1059 / 125975 . \mathrm{html}$ (2005). [: NCT00155337]

Goodin 2005 \{published data only\}

Goodin S. A phase II trial to assess the effects of green tea in oral leukoplakia. www.controlled-trials.com/mrct/trial/ NCT00176566/1059/126861.html (2005).

Lippman 2004 \{published data only\}

Lippman SM, Sudbo J. Celecoxib and/or erlotinib in preventing oral cancer in patients with oral leukoplakia. www.controlled-trials.com/mrct/trial/NCT00088842/ 1059/59769.html (2004). [: NCT00088842]

\section{Additional references}

\section{Abbey 1995}

Abbey LM, Kaugars GE, Gunsolley JC, Burns JC, Page DG, Svirsky JA, et al.Intraexaminer and interexaminer reliability in the diagnosis of oral epithelial dysplasia. Oral Surgery, Oral Medicine, Oral Pathology, Oral Radiology and Endodontics 1995;80(2):188-91.

\section{Axell 1984}

Axell T, Holmstrup P, Kramer IRH, Pindborg JJ. International seminar on oral leukoplakia and associated lesions related to tobacco habits. Community Dentistry and Oral Epidemiology 1984;12:145-54.

\section{Axell 1987}

Axell T. Occurrence of leukoplakia and some other oral white lesions among 20,333 adult Swedish people. Community Dentistry and Oral Epidemiology 1987;15(1): 46-51.

\section{Axell 1996}

Axell T, Pindborg JJ, Smith CJ, van der Waal I. Oral white lesions with special reference to precancerous and tobaccorelated lesions: conclusions of an international symposium held in Uppsala, Sweden, May 18-21 1994. International Collaborative Group on Oral White Lesions. Journal of Oral Pathology \& Medicine 1996;25(2):49-54. [MEDLINE: 1996237276]

\section{Bouquot 1986}

Bouquot JE, Gorlin RJ. Leukoplakia, lichen planus, and other oral keratoses in 23,616 white Americans over the age of 35 years. Oral Surgery, Oral Medicine and Oral Pathology 1986;61(4):373-81.

\section{Campisi 2004}

Campisi G, Giovannelli L, Arico P, Lama A, Di Liberto C, Ammatuna P, et al.HPV DNA in clinically different variants of oral leukoplakia and lichen planus. Oral Surgery, Oral Medicine, Oral Pathology, Oral Radiology, and Endodontics 2004;98(6):705-11.

\section{Curfman 2006}

Curfman GD, Morrissey S, Drazen JM. Expression of concern: Sudbo J et al. DNA content as a prognostic marker in patients with oral leukoplakia. N Engl J Med 2001;344:1270-8 and Sudbo J et al. the influence of resection and aneuploidy on mortality in oral leukoplakia. N Engl J Med 2004;350:1405-13. The New England Journal of Medicine 2006;354(6):638.

Dietrich 2004

Dietrich T, Reichart PA, Scheifele C. Clinical risk factors of oral leukoplakia in a representative sample of the US population. Oral Oncology 2004;40(2):158-63.

\section{Greenhalgh 1997}

Greenhalgh T. How to read a paper. The Medline database. BMJ 1997;315(7101):180-3. [MEDLINE: 1997395413]

\section{Gupta 1980}

Gupta PC, Mehta FS, Daftary DK, Pindborg JJ, Bhonsle $\mathrm{RB}$, Jalnawalla $\mathrm{PN}$, et al.Incidence rates of oral cancer and natural history of oral precancerous lesions in a 10-year follow-up study of Indian villagers. Community Dentistry and Oral Epidemiology 1980;8(6):283-33.

\section{Higgins 2005}

Higgins JPT, Green S, editors. Assessment of study quality. Cochrane Handbook for Systematic Reviews of Interventions 4.2.5 [updated May 2005]; Section 6. The Cochrane Library, Issue 3. Chichester, UK: John Wiley \& Sons, Ltd, 2005.

\section{Holmstrup 2006}

Holmstrup P, Vedtofte P, Reibel J, Stoltze K. Long-term treatment outcome of oral premalignant lesions. Oral Oncology 2006;42(5):461-74.

\section{Horton 2006}

Horton R. Retraction--Non-steroidal anti-inflammatory drugs and the risk of oral cancer: a nested case-control study. Lancet 2006;367(9508):382.

\section{Ikeda 1991}

Ikeda N, Ishii T, Iida S, Kawai T. Epidemiological study of oral leukoplakia based on mass screening for oral mucosal diseases in a selected Japanese population. Community Dentistry and Oral Epidemiology 1991;19(3):160-3.

Karabulut 1995

Karabulut A, Reibel J, Therkildsen MH, Praetorius F, Nielesen HW, Dabelsteen E. Observer variability in the histologic assessment of oral premalignant lesions. Journal of Oral Pathology Medicine 1995;24(5):198-200.

\section{Kramer 1978}

Kramer IR, Lucas RB, Pindborg JJ, Sobin LH. Definition of leukoplakia and related lesions: an aid to studies on oral precancer. Oral Surgery, Oral Medicine and Oral Pathology 1978;46(4):518-39. [MEDLINE: 1979053956]

Lee 2000

Lee JJ, Hong WK, Hittelman WN, Mao L, Lotan R, Shin DM, et al.Predicting cancer development in oral leukoplakia: ten years of translational research. Clinical Cancer Research 2000;6(5):1702-10. 
Lind 1987

Lind PO. Malignant transformation in oral leukoplakia. Scandinavian Journal of Dental Research 1987;95(6): 449-55.

Lumerman 1995

Lumerman H, Freedman P, Kerpel S. Oral epithelial dysplasia and the development of invasive squamous cell carcinoma. Oral Surgery, Oral Medicine, Oral Pathology, Oral Radiology and Endodontics 1995;79(3):321-9.

\section{Marley 1998}

Marley JJ, Cowan CG, Lamey PJ, Linden GJ, Johnson NW, Warnakulasuriya KA. Management of potentially malignant oral mucosal lesions by consultant UK oral and maxillofacial surgeons. British Journal of Oral and Maxillofacial Surgery 1998;34(1):28-36.

\section{Nagao 2005}

Nagao T, Ikeda N, Fukano H, Hashimoto S, Shimozato $\mathrm{K}$, Warnakulasuriya S. Incidence rates for oral leukoplakia and lichen planus in a Japanese population. Journal of Oral Pathology and Medicine 2005;34(9):532-9.

\section{Petti 2003}

Petti S. Pooled estimate of world leukoplakia prevalence: a systematic review. Oral Oncology 2003;39:770-80.

\section{Reichart 2000}

Reichart PA. Oral mucosal lesions in a representative crosssectional study of aging Germans. Community Dentistry and Oral Epidemiology 2000;28(5):390-8.

\section{Sackett 1997}

Sackett DL, Richardson WS, Rosenberg W, Haynes RB. Critically appraising the evidence. In: Sackett DL, Richardson WS, Rosenberg W, Haynes RB editor(s). Evidence-based medicine. How to practice and teach EBM. Churchill Livingstone, 1997:79-156.

\section{Saito 2001}

Saito T, Sugiura C, Hirai A, Notani K, Totsuka Y, Shindoh $\mathrm{M}$, et al.Development of squamous cell carcinoma from pre-existent oral leukoplakia: with respect to treatment modality. International Journal of Oral and Maxillofacial Surgery 2001;30(1):49-53.

\section{Scheifele 2003}

Scheifele C, Reichart PA. Is there a natural limit of the transformation rate of oral leukoplakia?. Oral Oncology 2003;39(5):470-5.

\section{Schepman 1998}

Schepman KP, van der Meij EH, Smeele LE, van der Waal I. Malignant transformation of oral leukoplakia: a followup study of a hospital-based population of 166 patients with oral leukoplakia from The Netherlands. Oral Oncology 1998;34(4):270-5.

\section{Scully 2000}

Scully C, Porter S. ABC of oral health. Oral cancer. BMJ 2000;321(7253):97-100.

\section{Shiu 2000}

Shiu MN, Chen TH, Chang SH, Hahn LJ. Risk factors for leukoplakia and malignant transformation to oral carcinoma: a leukoplakia cohort in Taiwan. British Journal of Cancer 2000;82(11):1871-4.

\section{Silverman 1984}

Silverman S Jr, Gorsky M, Lozada F. Oral leukoplakia and malignant transformation. A follow-up study of 257 patients. Cancer 1984;53(3):563-8.

\section{Warnakulasuriya 2000}

Warnakulasuriya S. Lack of molecular markers to predict malignant potential of oral precancer. Journal of Pathology 2000;190(4):407-9.

\section{Zhang 2001}

Zhang L, Rosin MP. Loss of heterozygosity: a potential tool in management of oral premalignant lesions?. Journal of Oral Pathology and Medicine 2001;30(9):513-20.

\section{Zhang 2005}

Zhang L, Williams M, Poh CF, Laronde D, Epstein JB, Durham $S$, et al.Toluidine blue staining identifies highrisk primary oral premalignant lesions with poor outcome. Cancer Research 2005;65(17):8017-21.

\section{References to other published versions of this review}

\section{Lodi 2002}

Lodi G, Sardella A, Bez C, Demarosi F, Carrassi A. Systematic review of randomized trials for the treatment of oral leukoplakia. Journal of Dental Education 2002;66(8): 896-902.

\section{Lodi 2004}

Lodi G, Sardella A, Bez C, Demarosi F, Carrassi A. Interventions for treating oral leukoplakia. Cochrane Database of Systematic Reviews 2004., Issue 3. [Art. No.: CD001829. DOI: 10.1002/14651858.CD001829.pub2]

* Indicates the major publication for the study 


\title{
CHARACTERISTICS OFSTUDIES
}

\section{Characteristics of included studies [ordered by study ID]}

\author{
Epstein 1994
}

\begin{tabular}{|c|c|c|}
\hline Methods & \multicolumn{2}{|c|}{$\begin{array}{l}\text { Randomised, parallel-group, double-blind, clinical trial. } \\
\text { Low risk of bias (RCT, double-blind, } 100 \% \text { of patients who entered the study were included in the final } \\
\text { analysis) }\end{array}$} \\
\hline Participants & \multicolumn{2}{|c|}{$\begin{array}{l}22 \text { patients: } 12 \text { females, mean age } 56.6 \text { (range } 25 \text { to } 79) \text {, ethnic group not reported, } 14 \text { (63\%) tobacco } \\
\text { users, } 10(45 \%) \text { alcohol users. Inclusion criteria: patients more than } 18 \text { years of age and with clinically } \\
\text { visible leukoplakia and pathologic diagnosis of the lesion. Exclusion criteria: pregnant women, women of } \\
\text { child bearing age in whom contraception was not confirmed, cases of carcinoma in situ, invasive SCC, } \\
\text { and lesions identified as inflammatory in nature. Diagnostic criteria for leukoplakia: histological diagnosis } \\
\text { of hyperkeratosis or acanthosis with or without dysplasia. } 22 \% \text { of the lesions were dysplastic }\end{array}$} \\
\hline Interventions & \multicolumn{2}{|c|}{$\begin{array}{l}1 \text { daily topical application of } 1 \% \text { w/v bleomycin in dimethylsulphoxide or placebo (dimethylsulphoxide } \\
\text { only), for } 14 \text { days. Mean FU since the end of treatment } 15 \text { months (bleomycin group) and } 22 \text { months } \\
\text { (placebo group). Compliance control: yes }\end{array}$} \\
\hline Outcomes & \multicolumn{2}{|c|}{$\begin{array}{l}\text { Measurement of the lesion and recording of signs and symptoms, before starting the treatment and weekly } \\
\text { during treatment. Complete response was defined as no clinical and histological evidence of leukoplakia. } \\
\text { Partial response was defined as a greater than } 50 \% \text { reduction in the size of lesion or elimination of } \\
\text { dysplasia. Assessment of oral burning and pain during application, between applications and with eating. } \\
\text { Histological grading before starting treatment and } 4 \text { weeks following treatment }\end{array}$} \\
\hline Notes & \multicolumn{2}{|c|}{$\begin{array}{l}\text { Following the post-treatment biopsy } 7 \text { patients of the placebo group were crossed over to receive } 1 \% \mathrm{w} / \mathrm{v} \\
\text { bleomycin in dimethylsulphoxide }\end{array}$} \\
\hline \multicolumn{3}{|l|}{ Risk of bias } \\
\hline Item & Authors' judgement & Description \\
\hline Allocation concealment? & Yes & A - Adequate \\
\hline
\end{tabular}

Gaeta 2000

Methods Quasi-randomised, parallel-group, double-blind, 3 arms clinical trial.

Moderate risk of bias (quasi-RCT, double-blind, $100 \%$ of patients who entered the study were included in the final analysis). Study duration: 4 weeks

Participants

21 patients: 5 females, mean age 52.5 (range 42 to 73), ethnic group not reported, tobacco users not reported, alcohol users not reported. Inclusion criteria: patients with histologically confirmed oral leukoplakia. Exclusion criteria: leukoplakia with severe dysplasia, impaired renal or hepatic functions, severe cardiological disease, woman in child bearing age. Histological criteria for leukoplakia: not reported. 29\% of the lesions were dysplastic, but they were all in the treatments arms 


\section{Gaeta 2000 (Continued)}

Interventions
$\begin{aligned} & 2 \text { daily topical application of a mucoadhesive slow release tablet for } 4 \text { weeks. The } 3 \text { groups received tablets } \\ & \text { with: (A) acitretin } 10 \mathrm{mg} \text { in methocel E5 } 55 \mathrm{mg} \text { or (B) acitretin } 10 \mathrm{mg} \text { in methocel E5 } 33 \mathrm{mg} \text { and lactose }\end{aligned}$
$23 \mathrm{mg}$ (C) methocel E5 $33 \mathrm{mg}$ and lactose $23 \mathrm{mg}$ (placebo). Compliance control: yes

Outcomes Clinical and histological grading was done before starting treatment and upon its completion. At baseline and on the 28th day of treatment: assessment of the lesion according to a descriptive clinical scale $(0=$ no evidence of disease, 1 = mild involvement, 2 = moderate involvement, 3 = severe involvement)

Notes

The 2 treatment arms have been pooled together in the meta-analysis

Risk of bias

\begin{tabular}{|c|c|c|}
\hline Item & Authors' judgement & Description \\
\hline Allocation concealment? & Unclear & B - Unclear \\
\hline
\end{tabular}

\section{Hong 1986}

\begin{tabular}{ll} 
Methods & $\begin{array}{l}\text { Randomised, parallel-group, double-blind, clinical trial. } \\
\text { Low risk of bias (RCT, double-blind, } 90 \% \text { of patients who entered the study were included in the final } \\
\text { analysis). Study duration: } 9 \text { months }\end{array}$ \\
\hline Participants & $\begin{array}{l}44 \text { patients: } 13 \text { females; age groups: }<50 \text { years: } 9 \text { patients, } 50 \text { to } 69 \text { years: } 29 \text { patients, }>70 \text { years: } 6 \\
\text { patients; ethnic group not reported; } 9(20 \%) \text { tobacco users, } 11(25 \%) \text { alcohol users, } 20(45 \%) \text { tobacco } \\
\text { + alcohol users. Inclusion criteria: histologically confirmed oral leukoplakia. Exclusion criteria: women } \\
\text { with reproductive capacity, persons taking megadoses of vitamin A ( }>25,000 \text { USP units/day), patients } \\
\text { who had had an oral cancer within the } 2 \text { years preceding the study. Histological criteria for leukoplakia: } \\
\text { not reported. } 27 \% \text { of the lesions were dysplastic }\end{array}$ \\
\hline
\end{tabular}

Interventions Capsules of placebo or 13-cis-retinoic acid ( 1 to $2 \mathrm{mg} / \mathrm{kg} / \mathrm{day}$ ), for 3 months. FU since the end of treatment: 6 months. Compliance control: yes

Outcomes

Measurement of the lesion, colour photography, laboratory studies (including fasting serum triglycerides and liver function test) were performed before starting the treatment and every 2 to 3 weeks during treatment. Complete response was defined as no clinical and histological evidence of leukoplakia for at least 4 weeks. Partial response was defined as a greater than $50 \%$ reduction in the product of the longest diameters of lesion. A response was classified as stable when the decrease in lesion size was less than $50 \%$. Disease progression was defined as an unequivocal increase in the size of any lesion during treatment or as the appearance of a new lesion. Histological grading was done before starting treatment and upon its completion. Histological grading included: 1 - atypical hyperplasia, 2 - mild dysplasia, 3 - moderate dysplasia, 4 - severe dysplasia or carcinoma in situ

Notes

\section{Risk of bias}

Item
Authors' judgement
Description 
Hong 1986 (Continued)

\begin{tabular}{|c|c|}
\hline Allocation concealment? & A - Adequate \\
\hline \multicolumn{2}{|l|}{ Li 1999} \\
\hline Methods & $\begin{array}{l}\text { Randomised, parallel-group, double-blind, clinical trial. } \\
\text { Moderate risk of bias (unclear methods of allocation, double-blind, } 92 \% \text { of patients who entered the } \\
\text { study were included in the final analysis) }\end{array}$ \\
\hline Participants & $\begin{array}{l}64 \text { patients: } 24 \text { females, mean age } 54.5 \text { (range } 23 \text { to } 78) \text {, ethnic group not reported, } 46(71.9 \%) \text { tobacco } \\
\text { users. Histological criteria for leukoplakia: not reported. } 20 \% \text { of the lesions were dysplastic }\end{array}$ \\
\hline Interventions & $\begin{array}{l}\text { Systemic (capsules) and topic (paint) placebo or systemic (capsules) and topic (paint) mixed tea ( } 3 \mathrm{~g} / \text { day } \\
\text { and } 3 \text { paintings/day), for } 6 \text { months. Compliance control: no }\end{array}$ \\
\hline Outcomes & $\begin{array}{l}\text { Size and number of lesions of each subject were recorded at the baseline and at the end of the trial. Oral } \\
\text { biopsies were conducted at the beginning and at the end of the trial. Besides routine histopathological } \\
\text { examination lesional tissue investigations included also silver stained nucleolar organizer regions (AgNOR) } \\
\text {, proliferation cell nuclear antigen (PCNA) and epidermal growth factor receptor (EGFR) analysis. A } \\
\text { complete regression was defined as the complete disappearance of the lesion. A partial regression was } \\
\text { defined as a 30\% or more reduction in the size of a single lesion or in the sum of sizes of multiple lesions. } \\
\text { Lesions with no change in size were recorded as no change. Deterioration referred to the occurrence of } \\
\text { new lesions }\end{array}$ \\
\hline Notes & \\
\hline
\end{tabular}

Risk of bias

\begin{tabular}{l|ll}
\hline Item & Authors' judgement & Description \\
\hline Allocation concealment? & Unclear & B - Unclear \\
\hline
\end{tabular}

Mulshine 2004

Methods

Randomised, parallel-group, double-blind, clinical trial.

Moderate risk of bias (unclear methods of allocation, double-blind, 98\% of patients who entered the study were included in the final analysis)

Participants

57 patients: 19 females; age not reported; ethnic group: non white subjects: 6/57, white subjects: 51/57; 48/ 56 (86\%) smokers, 40/56 (86\%) alcohol users. Inclusion criteria: subjects with bidimensionally measurable leukoplakia of the oral cavity or of the oral pharynx. In case of previous oral cancer diagnosis, individuals had to be free from diseases for at least 3 months, excellent performance status, general good health. Exclusion criteria: hypersensitivity to aspirin, lidocaine, NSAIDs, retinoids. Use of antibiotics, steroids, NSAIDs, aspirin, probenecid, antihistamines for least $>10$ consecutive days or any immunosuppressants, anticoagulants, dilantin, lithium, methotrexate, phenothiazines, or drugs that could compromise the test product safety during the 30 days immediately preceding the first treatment visit, debilitating oral conditions requiring extensive dental procedures or conditions interfering with compliance. Respiratory or cardiovascular problems. Histological criteria for leukoplakia: not reported. Percentage of dysplastic 
Mulshine 2004 (Continued)

lesions not reported

\begin{tabular}{ll}
\hline Interventions & $\begin{array}{l}\text { Mouthwash with placebo or ketorolac } 0.1 \% \text {, twice a day, for } 90 \text { days. FU since the end of treatment: } 1 \\
\text { month. Compliance control: yes }\end{array}$ \\
\hline Outcomes & $\begin{array}{l}\text { Measurement and histological assessment of the lesion. Complete response was defined as no clinical and } \\
\text { histological evidence of leukoplakia for at least } 30 \text { days. Partial response was defined as a greater than } 50 \% \\
\text { reduction in the product of the longest diameters of a single lesion or in the sum of these figures for all } \\
\text { lesions, for at least } 30 \text { days. A response was classified as stable when the decrease in lesion size was less } \\
\text { than } 50 \% \text {. Disease progression was defined as an unequivocal increase in the size greater than } 10 \% \text { or } \\
\text { as the appearance of a new lesion. Histological grading was done before starting treatment and upon its } \\
\text { completion }\end{array}$ \\
\end{tabular}

Notes

Data on histological changes were reported partially and did not allow extraction.

In the previous version of the review, this study was included among ongoing studies as Magnuson 2000

\section{Risk of bias}

\begin{tabular}{|c|c|c|}
\hline Item & Authors' judgement & Description \\
\hline Allocation concealment? & Unclear & B - Unclear \\
\hline
\end{tabular}

Piattelli 1999

\begin{tabular}{ll}
\hline Methods & $\begin{array}{l}\text { Randomised, parallel-group, double-blind, clinical trial. } \\
\text { Moderate risk of bias (unclear methods of allocation, double-blind, 90\% of patients who entered the } \\
\text { study were included in the final analysis) }\end{array}$ \\
\hline Participants & $\begin{array}{l}10 \text { patients: } 4 \text { females, mean age } 61 \text { (range } 40 \text { to } 71 \text { ), ethnic group: Caucasian, } 4 \text { (40\%) tobacco users. } \\
\text { Inclusion criteria: histologically confirmed oral leukoplakia. Exclusion criteria: women of child bearing } \\
\text { age. Histological criteria for leukoplakia: not reported. Mean duration of lesions: } 5.8 \text { years (range } 0.5 \text { to } \\
20 \text { years). Percentage of dysplastic lesions not reported }\end{array}$ \\
\hline Interventions & $\begin{array}{l}3 \text { times daily topical application of } 0.1 \% \text { isotretinoin (13-cis-retinoic acid - Roaccutane Roche) or placebo } \\
\text { (gel only), for } 14 \text { days. Compliance control: no }\end{array}$ \\
\hline Outcomes & $\begin{array}{l}\text { Measurement of the lesion, photography, laboratory studies (including serum cholesterol, triglycerides, } \\
\text { aspartate aminotransferase, alanine aminotransferase and alkaline phosphatase) were performed before } \\
\text { starting the treatment and every month during treatment. A complete response was defined as the complete } \\
\text { disappearance of the lesion as assessed by visual inspection, while a partial response was defined as a 50\% } \\
\text { or more reduction in the size of the lesions }\end{array}$ \\
\hline Notes & $\begin{array}{l}\text { At the end of the study period (4 months), patients who received placebo started a } 4 \text { months treatment } \\
\text { with active medication }\end{array}$ \\
\hline
\end{tabular}

Risk of bias

Item

Authors' judgement

Description

Interventions for treating oral leukoplakia (Review)

Copyright @ 2008 The Cochrane Collaboration. Published by John Wiley \& Sons, Ltd. 
Piattelli 1999 (Continued)

\begin{tabular}{l|l}
\hline Allocation concealment? & Unclear \\
\hline Sankaranarayan $\mathbf{1 9 9 7}$ & \\
\hline Methods & $\begin{array}{l}\text { Randomised, parallel-group, double-blind, } 3 \text { arms clinical trial. } \\
\text { Moderate risk of bias (methods of allocation unclear, double-blind, } 81 \% \text { of patients who entered the study } \\
\text { were included in the final analysis). Study duration: } 2 \text { years (1 year treatment }+1 \text { year FU) }\end{array}$ \\
\hline Participants & $\begin{array}{l}\text { 160 subjects with tobacco chewing habits and leukoplakia, belonging to the fisherman community of } \\
\text { Trivandrum City, Kerala, India, a population at high incidence of leukoplakia and oral cancer. Subject } \\
\text { details were available for the group of patients who completed the trial only (131 patients: } 47 \text { female; } \\
\text { mean age } 50.7 ; 127 \text { (97\%) chewers. 41 (31\%) smokers, } 72 \text { (55\%) drinkers. Inclusion criteria, exclusion } \\
\text { criteria and histological criteria not reported. Percentage of dysplastic lesions not reported }\end{array}$ \\
\hline
\end{tabular}

Interventions

Capsules of placebo or vitamin A (300,000 IU/week) or beta carotene (360 mg/week) for 1 year. FU since the end of treatment: 1 year. Compliance control: yes

Outcomes

Details of tobacco and alcohol habits, number, type and dimension of the lesion(s) were recorded at baseline and at each review. Laboratory studies (including estimation of retinol, tocopherols, carotenoids, trace elements, liver and kidney function test) were carried out before starting the treatment and at completion of it. Saliva and urine samples were collected from some of the subjects. Biopsies were taken at baseline and during the study, whenever a malignant transformation was suspected. Complete response was defined as no clinical and histological evidence of leukoplakia for at least 4 weeks. Partial response was defined as a greater than $50 \%$ reduction in the size of the single lesion or in the sum of sizes of multiple lesions. Stable and progressive lesions were scored as no response. Malignant transformation was scored if malignancy was histologically established in the lesions during FU

Notes

Risk of bias

\begin{tabular}{l|l|l}
\hline Item & Author' judgement & Description \\
\hline Allocation concealment? & Unclear & B - Unclear \\
\hline
\end{tabular}

Singh 2004

Methods

Randomised, parallel-group, double blind, 3 arms, clinical trial.

Moderate risk of bias (unclear methods of allocation, double blind, $100 \%$ of patients who entered the study were included in the final analysis)

Participants

58 patients: 14 females; age: 12 patients were between 10-30 years, 42 patients were between 31-60 years, 4 patients were between 61-80 years; ethnic group: not reported; smoking status: not reported; alcohol status: not reported. Inclusion criteria: not reported. Exclusion criteria: not reported. Histological criteria for leukoplakia: not reported. $59 \%$ of the lesions were dysplastic 


\section{Singh 2004 (Continued)}

\begin{tabular}{|c|c|c|}
\hline Interventions & \multicolumn{2}{|c|}{$\begin{array}{l}\text { Capsules of placebo or lycopene at high dose }(8 \mathrm{mg}) \text { or lycopene at low dose }(4 \mathrm{mg}) \text {, divided in } 2 \text { daily } \\
\text { doses for } 3 \text { months. FU since the end of treatment: } 2 \text { months. Compliance control: no }\end{array}$} \\
\hline Outcomes & \multicolumn{2}{|c|}{$\begin{array}{l}\text { Clinical measurement and histological grading was done before starting treatment and upon its completion. } \\
\text { Complete response was defined as no clinical and histological evidence of leukoplakia for at least } 4 \text { weeks. } \\
\text { Partial response was defined as a greater than } 50 \% \text { reduction in the product of the longest diameters of } \\
\text { lesion. A response was classified as stable when the decrease in lesion size was less than } 50 \% \text {. Disease } \\
\text { progression was defined as an unequivocal increase in the size of any lesion during treatment or as the } \\
\text { appearance of a new lesion. Histological grading included: } 1 \text { - atypical hyperplasia, } 2 \text { - mild dysplasia, } 3 \text { - } \\
\text { moderate dysplasia, } 4 \text { - severe dysplasia or carcinoma in situ }\end{array}$} \\
\hline Notes & \multicolumn{2}{|c|}{ The 2 treatment arms have been pooled together in the meta-analysis } \\
\hline \multicolumn{3}{|l|}{ Risk of bias } \\
\hline Item & Authors' judgement & Description \\
\hline Allocation concealment? & Unclear & B - Unclear \\
\hline
\end{tabular}

Stich 1988

Rethods
$\begin{aligned} & \text { Randomised, parallel-group, clinical trial. } \\ & \text { entered the study were included in the final analysis) }\end{aligned}$

Participants 65 patients with tobacco chewing habits and leukoplakia, belonging to the fisherman community of Trivandrum City, Kerala, India, a population at high incidence of leukoplakia and oral cancer. $2 \%$ tobacco users, $37 \%$ alcohol users, $28 \%$ tobacco + alcohol users. Inclusion criteria: betel quid chewers. Exclusion criteria: not specified. Diagnostic criteria for leukoplakia: WHO 1978. Percentage of dysplastic lesions not reported

Interventions

Capsules of placebo or vitamin A (200,000 IU/week) for 6 months. Compliance control: yes

Outcomes

Leukoplakias were evaluated and biopsies were taken before starting the treatment and at the end of study (6 months). At the end of study, patients were included in one of the following categories: remission of leukoplakia, no change, development of new leukoplakia. Histological markers evaluated were: 1 loss of polarity of basal cells, 2 lymphocytic infiltration, 3 nuclei with condensed chromatin

Notes

Questionnaires completed during the trial demonstrated that habits such as chewing, smoking and drinking, did not change during the course of the study.

Data on histology were available for only 18 patients of the study group and from none of the control group

Risk of bias

\begin{tabular}{l|l}
\hline Item & Authors' judgement
\end{tabular}

Interventions for treating oral leukoplakia (Review) 
Stich 1988 (Continued)

$\begin{array}{lll}\text { Allocation concealment? Unclear } & \text { B - Unclear }\end{array}$

$\mathrm{FU}=$ follow up

$\mathrm{RCT}=$ randomised controlled trial

$\mathrm{SCC}=$ squamous cell carcinoma

\section{Characteristics of excluded studies [ordered by study ID]}

\begin{tabular}{|c|c|}
\hline Study & Reason for exclusion \\
\hline Bocharova 2004 & $\begin{array}{l}\text { The study was not randomised, and both arms of the study employed active treatments, i.e. no placebo (or } \\
\text { no treatment) group was included in the study }\end{array}$ \\
\hline Boisnic 1994 & The study included patients with traumatic lesions. \\
\hline Chiesa 2005 & $\begin{array}{l}\text { All patients underwent active treatment. The aim of the treatment tested being to prevent recurrence of } \\
\text { leukoplakia, all patients were randomised after surgical removal (active treatment) of the oral lesion }\end{array}$ \\
\hline Femiano 2001 & Patients were allocated to the arms of the study by the researchers \\
\hline Garewal 1999 & $\begin{array}{l}\text { The patients randomised were a selected group of subjects who responded to the drug tested in the randomised } \\
\text { phase (beta carotene) }\end{array}$ \\
\hline Krishnaswamy 1995 & $\begin{array}{l}\text { The study had inadequate method of allocation and only } 66 \% \text { of patients had lesions, none with an histological } \\
\text { diagnosis }\end{array}$ \\
\hline Lippman 1993 & $\begin{array}{l}\text { The patients randomised were a selected group of subjects who responded to one of the two drugs tested in } \\
\text { the randomised phase (isotretinoin) }\end{array}$ \\
\hline Mathew 1995 & The study was not randomised, as controls were taken from another study control group \\
\hline Schwarz 2005 & $\begin{array}{l}\text { Both arms of the study employed active treatments, i.e. no placebo (or no treatment) group was included in } \\
\text { the study }\end{array}$ \\
\hline Sun 1996 & Animal study. \\
\hline Zaridze 1993 & $\begin{array}{l}\text { The oral lesions diagnosed as leukoplakia were not biopsied for histological examination. Data, as presented } \\
\text { in the paper, do not allow the analysis }\end{array}$ \\
\hline
\end{tabular}


Characteristics of ongoing studies [ordered by study ID]

\section{Beenken 2000}

Trial name or title Fenretinide in treating patients with leukoplakia of the mouth

Methods

Participants
Inclusion criteria: (a) histologically proven dysplastic leukoplakia greater than $1 \mathrm{~cm}$ in diameter; (b) at least 3
months since prior chronic high dose (greater than $30,000 \mathrm{IU} /$ day) vitamin A (retinol), at least $1 \mathrm{month}$ since
other prior retinoids; (c) 18 years and over; (d) WBC at least $3500 / \mathrm{mm} 3$, platelet count at least $125,000 /$
$\mathrm{mm} 3$, haemoglobin at least $12.0 \mathrm{~g} / \mathrm{dL}$, bilirubin less than 2 times upper limit of normal, creatinine less than
$1.7 \mathrm{mg} / \mathrm{dL} ;(\mathrm{e})$ no symptomatic coronary artery disease, no uncontrolled hypertension, no prior coronary
artery bypass, no acute myocardial infarction in the past year; (f) not pregnant or nursing, negative pregnancy
test, fertile patients must use effective barrier contraception for 1 month prior, during and for 12 months after
study; (g) fasting serum triglyceride less than 2 times upper limit of normal, cholesterol less than 350 mg/dL;
(h) no hypersensitivity to vitamin A or retinoids; (i) no active malignancy, no concurrent acute or chronic
medical or psychiatric condition that would preclude compliance or toxicity assessment; (j) no concurrent
and severe night blindness

Interventions A total of 30 patients will be accrued for this study. Treatment patients receive oral fenretinide daily (except days 1 to 3 each month) for 6 months. Control patients receive oral placebo daily (except days 1 to 3 each month) for 6 months and then receive oral fenretinide daily (except days 1 to 3 each month) for 6 months. Patients are followed up every 3 months

Outcomes

Starting date

February 2000 .

Contact information

Notes

Boyle 2000

Trial name or title Celecoxib in treating patients with precancerous lesions of the mouth

Methods

Participants

Inclusion criteria: (a) histologically confirmed index oral premalignant lesion; (b) at least 3 weeks since prior immunotherapy, chemotherapy, hormonal therapy, chemopreventive therapy; (c) at least 2 weeks since prior beta carotene at $60 \mathrm{mg} /$ day or more, no concurrent beta carotene at $60 \mathrm{mg} /$ day or more, no concurrent oral aspirin greater than $100 \mathrm{mg} /$ day, no other concurrent investigational agents, no concurrent fluconazole or lithium, no concurrent chronic NSAIDs or COX-2 inhibitors; (d) less than 14 days of oral or IV corticosteroid use within the past 6 months, less than 30 days of inhaled corticosteroid use within the past 6 months; (e) at least 3 weeks since prior radiotherapy; (f) age over 18 and performance status: Zubrod 0 to 1 ; (g) life expectancy: more than 12 weeks; (h) ematopoietic: haemoglobin greater than lower limit of normal, WBC greater than $3000 / \mathrm{mm} 3$, platelet count greater than $125,000 / \mathrm{mm} 3$, no significant bleeding disorder; (i) hepatic: bilirubin no greater than 1.5 times upper limit of normal (ULN), AST/ALT no greater than 1.5 times ULN, no chronic or acute hepatic disorder; (j) renal: BUN no greater than 1.5 times ULN, creatinine no greater than 1.5 times ULN, no chronic or acute renal disorder; $(\mathrm{k})$ gastrointestinal: no diagnosis or 
Boyle 2000 (Continued)

treatment of oesophageal, gastric, pyloric channel, or duodenal ulceration within past 30 days, no prior or active pancreatic disease or inflammatory bowel disease; (l) other: completed a smoking cessation program, if applicable, no prior hypersensitivity to COX-2 inhibitors, NSAIDs, salicylates, or sulphonamides, no prior invasive cancer within the past 5 years except non-melanoma skin cancer or carcinoma in situ of the cervix, no other concurrent condition that would preclude study, not pregnant or nursing, negative pregnancy test, fertile patients must use effective contraception

Interventions

Arm I: patients receive lower-dose oral celecoxib twice daily. Arm II: patients receive higher-dose oral celecoxib twice daily. Arm III: patients receive oral placebo twice daily. Treatment continues in all 3 arms for 12 weeks in the absence of disease progression or unacceptable toxicity. Patients are followed at 18, 24, and 26 weeks

Outcomes

Starting date

October 2000.

Contact information Jay O Boyle, Study Chair, Memorial Sloan-Kettering Cancer Center

Notes This study is no longer recruiting patients.

Chiang 2005

Trial name or title Photodynamic therapy for oral leukoplakia and erythroleukoplakia

\begin{tabular}{l|l}
\hline Methods & \\
\hline Participants & Inclusion criteria: patients with leukoplakia or erythroleukoplakia. Exclusion criteria: oral cancers \\
\hline Interventions & Photodynamic therapy. \\
\hline Outcomes & August 2004. \\
\hline Starting date & $\begin{array}{l}\text { Chun-Pin Chiang DMSc } \\
\text { tel: }+886223123456 \text { ext: } 6855 \\
\text { cpchiang@ha.mc.ntu.edu.tw }\end{array}$ \\
\hline Contact information & Recruiting. \\
\hline Notes &
\end{tabular}

Goodin 2005

Trial name or title A phase II trial to assess the effects of green tea in oral leukoplakia

Methods

Interventions for treating oral leukoplakia (Review) 


\section{Goodin 2005 (Continued)}

\begin{tabular}{l|l}
\hline Participants & $\begin{array}{l}\text { Patients with oral leukoplakia without evidence of active infections in the mouth will be invited to participate } \\
\text { in this study. Patients must currently consume no more than } 3 \text { cups of tea a day, not be taking large doses of } \\
\text { vitamin A or its derivatives (more than 25,000 units), selenium, or beta carotene. Additionally, patients must } \\
\text { not participate in this study if they are allergic to caffeine, have GI ulcers, are pregnant, or have had previous } \\
\text { invasive mouth cancer }\end{array}$ \\
\hline Interventions & Green tea lozenge versus placebo. \\
\hline Outcomes & November 2003. \\
\hline Starting date & Susan Goodin PharmD, University of Medicine and Dentistry New Jersey \\
\hline Contact information & \\
\hline Notes
\end{tabular}

Lippman 2004

Trial name or title Celecoxib or erlotinib or both in preventing oral cancer in patients with oral leukoplakia

\begin{tabular}{l|l}
\hline Methods & \\
\hline Participants & $\begin{array}{l}\text { Inclusion criteria: (a) diagnosis of oral aneuploid premalignant lesion within the past } 3 \text { months; (b) dysplastic } \\
\text { white or red patches in the oral cavity with DNA aneuploidy determined by high resolving image cytometry; } \\
\text { (c) must have sufficient lesion to biopsy; (d) no prior or active head and neck cancer or lung cancer; (e) no } \\
\text { known metastases to the head and neck area from other tumours }\end{array}$ \\
\hline Interventions & $\begin{array}{l}\text { Celecoxib or erlotinib or both may be effective in preventing the development of oral cancer in patients who } \\
\text { have oral leukoplakia }\end{array}$ \\
\hline Outcomes & Scott M. Lippman MD, FACP, M.D. Anderson Cancer Center. \\
\hline Starting date & Not yet recruiting. \\
\hline Nontact information & Sotes
\end{tabular}


DATA ANDANALYSES

Comparison 1. Topical or systemic treatment versus placebo

\begin{tabular}{|c|c|c|c|c|}
\hline Outcome or subgroup title & $\begin{array}{l}\text { No. of } \\
\text { studies }\end{array}$ & $\begin{array}{c}\text { No. of } \\
\text { participants }\end{array}$ & Statistical method & Effect size \\
\hline 1 Malignant transformation & 2 & & Risk Ratio (M-H, Random, 95\% CI) & Totals not selected \\
\hline 1.1 Topical bleomycin & 1 & & Risk Ratio (M-H, Random, 95\% CI) & Not estimable \\
\hline 1.2 Systemic vitamin A & 1 & & Risk Ratio (M-H, Random, 95\% CI) & Not estimable \\
\hline 1.3 Systemic beta carotene & 1 & & Risk Ratio (M-H, Random, 95\% CI) & Not estimable \\
\hline $\begin{array}{l}2 \text { Oral lesion not completely } \\
\text { resolved }\end{array}$ & 9 & & Risk Ratio (M-H, Random, 95\% CI) & Subtotals only \\
\hline 2.1 Topical bleomycin & 1 & 22 & Risk Ratio (M-H, Random, 95\% CI) & $0.55[0.29,1.04]$ \\
\hline 2.2 Tea (topical plus systemic) & 1 & 64 & Risk Ratio (M-H, Random, 95\% CI) & Not estimable \\
\hline 2.3 Vitamin A or retinoids & 5 & 245 & Risk Ratio (M-H, Random, 95\% CI) & $0.70[0.52,0.94]$ \\
\hline $\begin{array}{l}2.4 \text { Systemic beta carotene or } \\
\text { carotenoids }\end{array}$ & 2 & 168 & Risk Ratio (M-H, Random, 95\% CI) & $0.70[0.57,0.87]$ \\
\hline 2.5 Ketorolac oral rinse & 1 & 57 & Risk Ratio (M-H, Random, 95\% CI) & $0.94[0.81,1.10]$ \\
\hline $\begin{array}{l}3 \text { Histological features not } \\
\text { improved }\end{array}$ & 3 & & Risk Ratio (M-H, Random, 95\% CI) & Totals not selected \\
\hline 3.1 Topical bleomycin & 1 & & Risk Ratio (M-H, Random, 95\% CI) & Not estimable \\
\hline 3.2 Retinoids & 1 & & Risk Ratio (M-H, Random, 95\% CI) & Not estimable \\
\hline $\begin{array}{l}3.3 \text { Systemic beta carotene or } \\
\text { carotenoids }\end{array}$ & 1 & & Risk Ratio (M-H, Random, 95\% CI) & Not estimable \\
\hline
\end{tabular}

\section{Analysis I.I. Comparison I Topical or systemic treatment versus placebo, Outcome I Malignant transformation.}

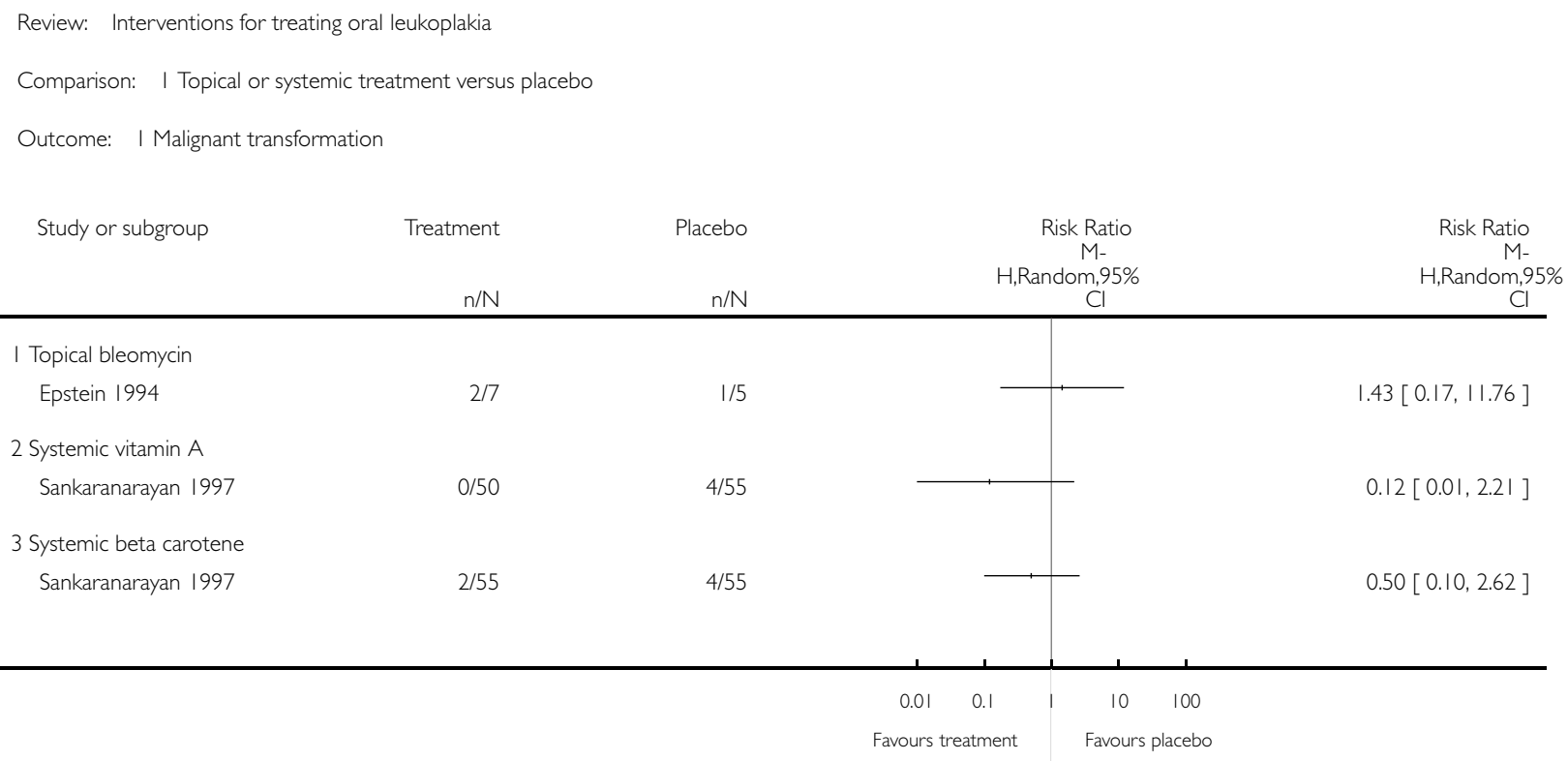

Interventions for treating oral leukoplakia (Review) 


\section{Analysis I.2. Comparison I Topical or systemic treatment versus placebo, Outcome 2 Oral lesion not}

completely resolved.

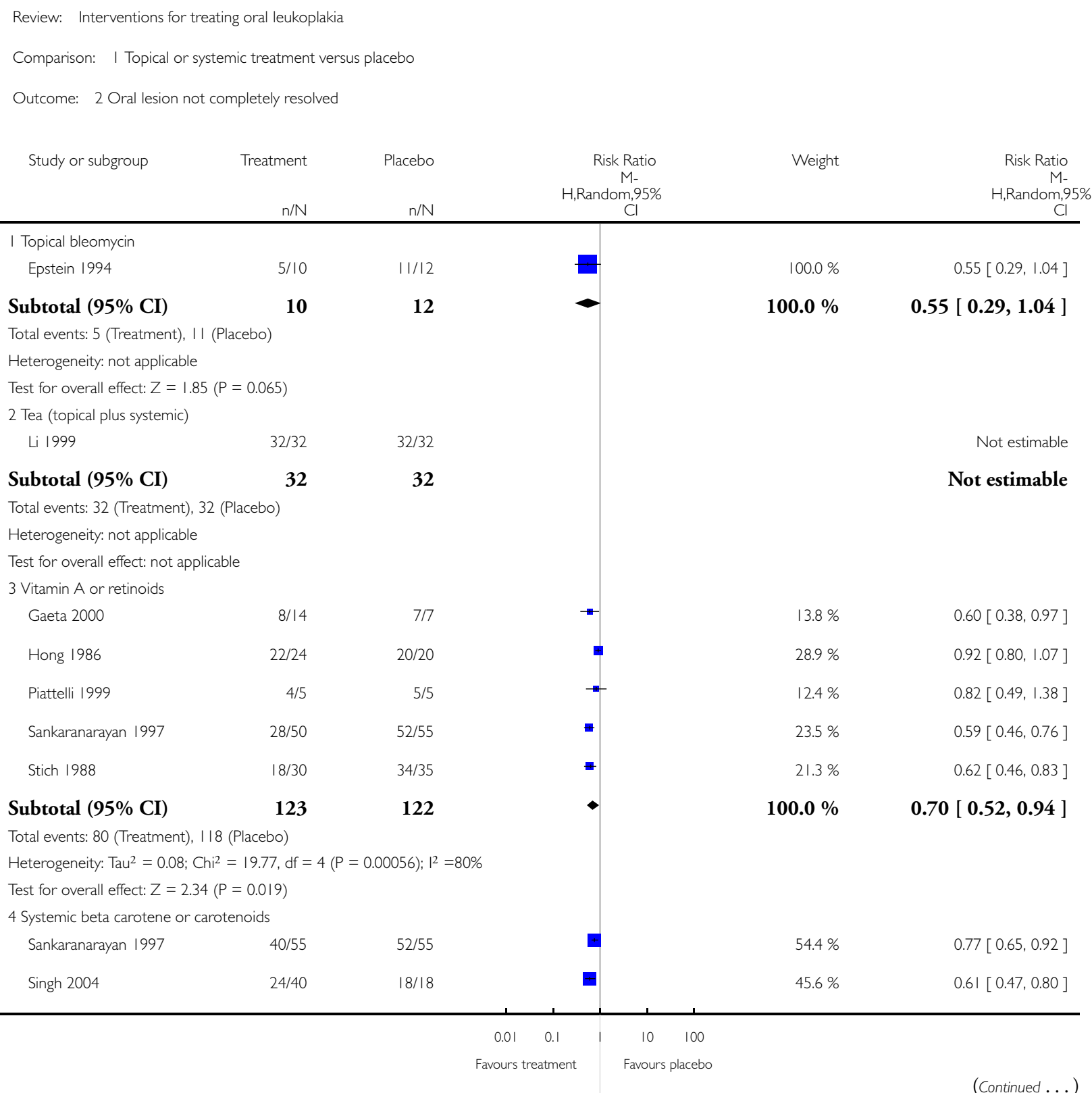




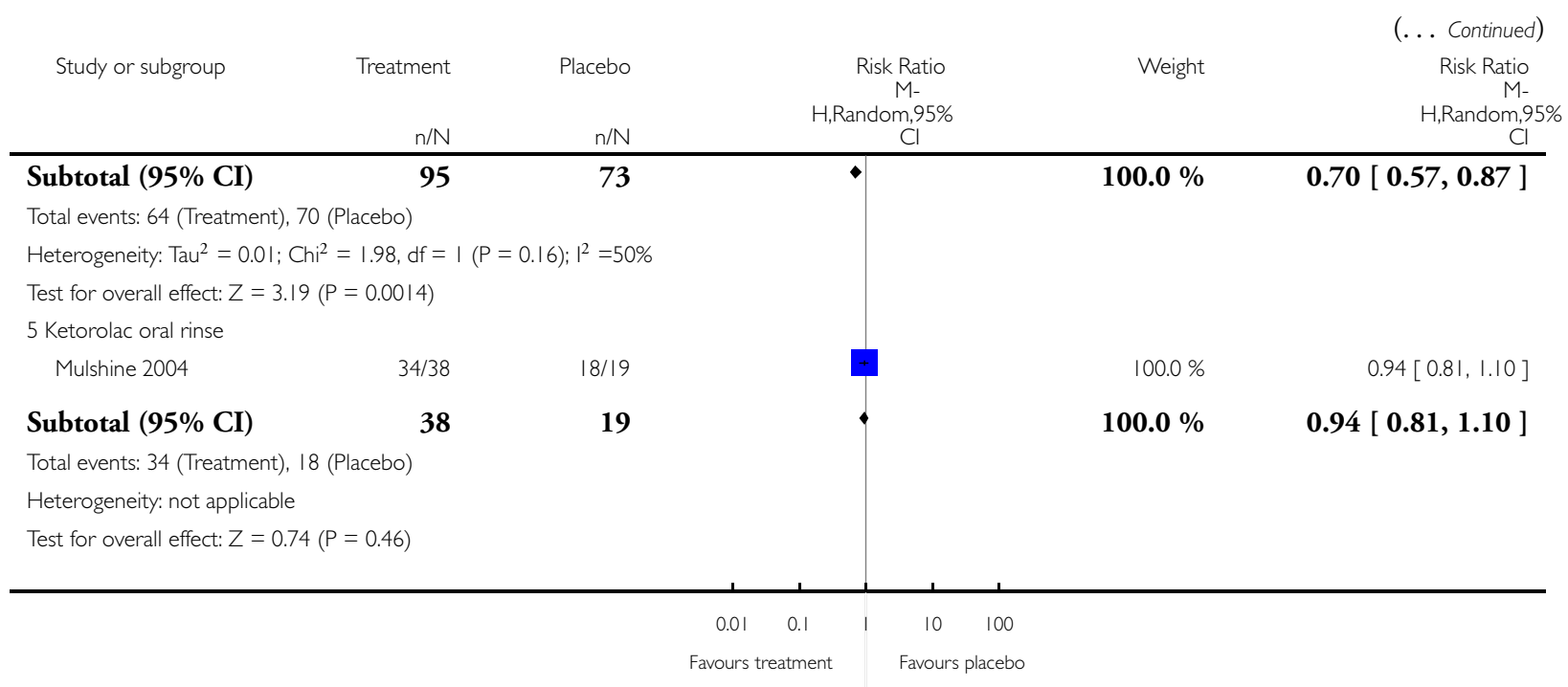

\section{Analysis I.3. Comparison I Topical or systemic treatment versus placebo, Outcome 3 Histological features not improved.}

\begin{tabular}{|c|c|c|c|c|}
\hline \multicolumn{5}{|c|}{ Comparison: I Topical or systemic treatment versus placebo } \\
\hline \multicolumn{5}{|c|}{ Outcome: 3 Histological features not improved } \\
\hline Study or subgroup & Treatment & $\begin{array}{r}\text { Placebo } \\
\text { n/N }\end{array}$ & $\begin{array}{c}\text { Risk Ratio } \\
\text { M- } \\
\text { H,Random,95\% } \\
\text { Cl }\end{array}$ & $\begin{array}{c}\text { Risk Ratio } \\
\text { M- } \\
\text { H,Random,95\% } \\
\text { Cl }\end{array}$ \\
\hline \multicolumn{5}{|l|}{ I Topical bleomycin } \\
\hline Epstein 1994 & $4 / 10$ & $9 / 12$ & 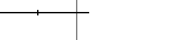 & $0.53[0.23,1.22]$ \\
\hline \multicolumn{5}{|l|}{2 Retinoids } \\
\hline Hong 1986 & $11 / 24$ & $18 / 20$ & $\longrightarrow$ & $0.51[0.32,0.81]$ \\
\hline \multicolumn{5}{|c|}{3 Systemic beta carotene or carotenoids } \\
\hline Singh 2004 & $8 / 40$ & $15 / 18$ & - & $0.24[0.12,0.46]$ \\
\hline
\end{tabular}


ADDITIONAL TABLES

Table 1. Patients referring adverse effects

\begin{tabular}{|c|c|c|c|c|}
\hline Study & Arms & Active treatment & Placebo & Adverse effects \\
\hline Epstein 1994 & $\begin{array}{l}\text { topical bleomycin versus } \\
\text { placebo }\end{array}$ & $10 / 10$ & $0 / 12$ & $\begin{array}{l}\text { erythem and erosion }(100 \%) \text {, discomfort } \\
(60 \%)\end{array}$ \\
\hline Gaeta 2000 & $\begin{array}{l}\text { topical acitretin (with } \\
\text { and without lactose) ver- } \\
\text { sus placebo }\end{array}$ & $0 / 14$ & $0 / 7$ & \\
\hline Hong 1986 & $\begin{array}{l}\text { systemic } 13 \text {-cis-retinoic } \\
\text { acid (from } 1 \text { to } 2 \mathrm{mg} / \mathrm{kg} \\
\text { per day) versus placebo }\end{array}$ & $19 / 24$ & $4 / 20$ & $\begin{array}{l}\text { cheilitis, facial erythema, dryness and peeling } \\
\text { of skin, conjunctivitis, hypertrigliceridemia }\end{array}$ \\
\hline Li 1999 & $\begin{array}{l}\text { systemic and topical tea } \\
\text { versus placebo }\end{array}$ & $0 / 32$ & $0 / 32$ & \\
\hline Mulshine 2004 & $\begin{array}{l}\text { ketorolac oral rinse ver- } \\
\text { sus placebo }\end{array}$ & $11 / 38$ & $3 / 19$ & pain, toxicity grade 1 and 2 \\
\hline Piattelli 1999 & $\begin{array}{l}\text { topical } 13 \text {-cis-retinoic } \\
\text { acid versus placebo }\end{array}$ & $0 / 5$ & $0 / 5$ & \\
\hline Sankaranarayanan 1997 & $\begin{array}{l}\text { vitamin A }(300,000 \text { IU } \\
\text { per week) versus placebo }\end{array}$ & $13 / 50$ & $1 / 55$ & headache, muscular pain, dry mouth \\
\hline Sankaranarayanan 1997 & $\begin{array}{l}\text { beta carotene ( } 360 \mathrm{mg} \\
\text { per week) versus placebo }\end{array}$ & $5 / 55$ & $1 / 55$ & headache, muscular pain \\
\hline Singh 2004 & $\begin{array}{l}\text { lycopene ( } 8 \mathrm{mg} \text { or } 4 \mathrm{mg} \text { ) } \\
\text { versus placebo }\end{array}$ & $0 / 40$ & $0 / 18$ & \\
\hline Stich 1988 & $\begin{array}{l}\text { vitamin A }(200,000 \mathrm{IU} \\
\text { per week) versus placebo }\end{array}$ & $0 / 30$ & $0 / 35$ & \\
\hline
\end{tabular}

Table 2. Patients leaving the study

\begin{tabular}{|c|c|c|c|c|}
\hline Study & Arms & Active treatment & Placebo & \\
\hline Epstein 1994 & $\begin{array}{l}\text { topical bleomycin versus } \\
\text { placebo }\end{array}$ & $0 / 10$ & $1 / 12$ & double-blind study \\
\hline Gaeta 2000 & $\begin{array}{l}\text { topical acitretin (with } \\
\text { and without lactose) ver- } \\
\text { sus placebo }\end{array}$ & $0 / 14$ & $0 / 7$ & double-blind study \\
\hline
\end{tabular}


Table 2. Patients leaving the study (Continued)

\begin{tabular}{|c|c|c|c|c|}
\hline Hong 1986 & $\begin{array}{l}\text { systemic } 13 \text {-cis-retinoic } \\
\text { acid (from } 1 \text { to } 2 \mathrm{mg} / \mathrm{kg} \\
\text { per day) versus placebo }\end{array}$ & $2 / 24$ & $2 / 20$ & double-blind study \\
\hline Li 1999 & $\begin{array}{l}\text { systemic and topical tea } \\
\text { versus placebo }\end{array}$ & $3 / 32$ & $2 / 32$ & double-blind study \\
\hline Mulshine 2004 & $\begin{array}{l}\text { ketorolac oral rinse ver- } \\
\text { sus placebo }\end{array}$ & $1 / 38$ & $0 / 19$ & double-blind study \\
\hline Piattelli 1999 & $\begin{array}{l}\text { topical } 13 \text {-cis-retinoic } \\
\text { acid versus placebo }\end{array}$ & $0 / 5$ & $1 / 5$ & double-blind study \\
\hline Sankaranarayanan 1997 & $\begin{array}{l}\text { vitamin A }(300,000 \mathrm{IU} \\
\text { per week) versus placebo }\end{array}$ & $8 / 50$ & $12 / 55$ & double-blind study \\
\hline Sankaranarayanan 1997 & $\begin{array}{l}\text { beta carotene ( } 360 \mathrm{mg} \\
\text { per week) versus placebo }\end{array}$ & $9 / 55$ & $12 / 55$ & double-blind study \\
\hline Singh 2004 & $\begin{array}{l}\text { lycopene ( } 8 \mathrm{mg} \text { or } 4 \mathrm{mg} \text { ) } \\
\text { versus placebo }\end{array}$ & $0 / 40$ & $0 / 18$ & double-blind study \\
\hline Stich 1988 & $\begin{array}{l}\text { vitamin A }(200,000 \mathrm{IU} \\
\text { per week) versus placebo }\end{array}$ & $9 / 30$ & $2 / 35$ & blindness not stated \\
\hline
\end{tabular}

\section{AP PENDICES}

\section{Appendix I. CENTRAL search strategy}

\#1 LEUKOPLAKIA ORAL explode all trees $(\mathrm{MeSH})$

\#2 leukoplaki*

\#3 preneoplastic NEAR oral

\#4 precancer* $^{*} \mathrm{NEAR}$ oral

\#5 (\#1 OR \#2 OR \#3 OR \#4) 


\section{WHAT'S NEW}

Last assessed as up-to-date: 3 July 2006.

\begin{tabular}{l|ll}
\hline Date & Event & Description \\
\hline 5 August 2008 & Amended & Converted to new review format. \\
\hline
\end{tabular}

\section{H I S T O R Y}

Protocol first published: Issue 3, 1999

Review first published: Issue 4, 2001

\begin{tabular}{l|l|l}
\hline Date & Event & Description \\
\hline 4 July 2006 & New citation required but conclusions have not changed & $\begin{array}{l}\text { Review updated. Two new included studies (Mulshine } \\
\text { 2004; Singh 2004), three ongoing studies, three excluded } \\
\text { studies. Conclusions remained essentially the same }\end{array}$ \\
\hline 25 May 2004 & New citation required but conclusions have not changed & $\begin{array}{l}\text { Review updated. One new study (Gaeta 2000) has been } \\
\text { included, however the summary estimates did not change } \\
\text { significantly and conclusions remained essentially the } \\
\text { same }\end{array}$ \\
\hline
\end{tabular}

\section{CONTRIBUTIONSOFAUTHORS}

Giovanni Lodi: main review author, participation in all phases of the review's preparation.

Cristina Bez: articles retrieval, data collection, interpretation of results.

Antonio Carrassi: group co-ordinator, selection of articles, interpretation of results.

Federica Demarosi: prospective handsearching, data collection, interpretation of results.

Andrea Sardella: selection of articles, critical appraisal of studies, interpretation of results. 


\section{DECLARATIONSOF INTEREST}

None known.

\section{SOURCES OF SUPPORT}

\section{Internal sources}

- University of Milan, Italy.

\section{External sources}

- No sources of support supplied

\section{INDEX TERMS}

\section{Medical Subject Headings (MeSH)}

Leukoplakia, Oral [*therapy]; Randomized Controlled Trials as Topic

\section{MeSH check words}

Humans 